PRZEGLĄD NAUK HISTORYCZNYCH 2020, R. XIX, NR 2

https://doi.org/10.18778/1644-857X.19.02.03

WiTOLD FILIPCZAK

UNIWERSYTET ŁÓDZKI*

iD https://orcid.org/0000-0001-5953-2480

\title{
Uwagi o sejmikach litewskich w czasach Rady Nieustającej na tle praktyki parlamentarnej powiatu kowieńskiego
}

Streszczenie. W artykule omówiono wybrane aspekty funkcjonowania sejmików litewskich w czasach Rady Nieustającej (zwłaszcza w latach 1776-1786). Wykorzystane zostały wiadomości na temat powiatu kowieńskiego znane dzięki Aktom sejmiku kowieńskiego w latach 1733-1795 opublikowanym w 2019 r. przez Monikę Jusupović. Informacje te skonfrontowano $z$ danymi dotyczacymi sejmików lidzkiego i wiłkomierskiego pochodzącymi $z$ kwerendy źródłowej w archiwach w Mińsku i Wilnie. Do celów porównawczych wykorzystane zostały wyniki badań historyków litewskich (sejmik wileński), polskich i białoruskich. W tekście przedstawiono m.in. takie zagadnienia, jak funkcjonowanie sejmików gospodarskich, relacyjnych i elekcyjnych. Zaprezentowano także informacje dotyczące typów akt sejmikowych, które są charakterystyczne dla parlamentaryzmu litewskiego. Omówione zostały dodatkowe wiadomości związane $z$ życiem politycznym powiatu kowieńskiego, których nie uwzględniła M. Jusupović. W końcowej części artykułu wyeksponowane sa specyficzne aspekty badań nad litewskim parlamentaryzmem. Dzięki zwyczajowi podpisywania uchwał sejmiku przez ogół osób w nim uczestniczacych możliwe jest przybliżone oszacowanie liczebności zgromadzenia. W drugiej połowie XVIII w. nadal istniały znaczące różnice między sejmikami litewskimi a koronnymi, choć widoczna jest tendencja do upodobniania się modeli funkcjonujących w obu krajach.

Słowa kluczowe: sejmiki, parlamentaryzm, Wielkie Księstwo Litewskie w XVIII w., Kowno, Lida, Wiłkomierz.

\footnotetext{
Cjmiki litewskie w czasach panowania Stanisława Augusta $S$ Poniatowskiego nie sa obszarem badawczym, który cieszy się wśród historyków polskich dużym zainteresowaniem. Zapewne

* Wydział Filozoficzno-Historyczny, Instytut Historii, Katedra Historii Nowożytnej, e-mail: witold.filipczak@uni.lodz.pl
} 
wpływ na to ma to, że podstawowe zasoby źródłowe, księgi sądowe $z$ obszaru Wielkiego Księstwa Litewskiego, znajdują się w Mińsku i Wilnie, co nie ułatwia kwerendy, a ponadto wydłuża proces zbierania materiałów. Istotna pomocą może więc stać się publikacja Akt sejmiku kowieńskiego z lat 1733-1795'. Wydawnictwo jest efektem wieloletniego zainteresowania Moniki Jusupović dziejami politycznymi powiatu kowieńskiego ${ }^{2}$. Opublikowane dokumenty poprzedzone zostały wstępem badaczki. Autorka zawarła w nim szereg ustaleń dotyczących funkcjonowania sejmików litewskich, kowieńskich w szczególności ${ }^{3}$. Zachęciło mnie to do uzupełnienia lub rozwinięcia niektórych zagadnień, a czasami także ich korekty. Odwołując się do wiadomości o sejmikach kowieńskich, przedstawię własne ustalenia dotyczące funkcjonowania sejmików litewskich w latach 1776-1786. Moje refleksje nad specyfika sejmiku kowieńskiego na tle zgromadzeń w Wielkim Księstwie Litewskim nie odnoszą się do nich całościowo. Nawiążę przede wszystkim do sejmików powiatów wiłkomierskiego i lidzkiego (w latach 1776-1786) ${ }^{4}$. Postaram się też wykorzystać ustalenia literatury przedmiotu, zwłaszcza wyniki uzyskane przez historyków litewskich. W wielu sprawach dostarczaja one cennego materiału o charakterze porównawczym. Mam na myśli prace Robertasa Jurgaitisa dotyczące dziejów sejmiku wileńskiego w latach 1717-1795 (dysertację i monografię) ${ }^{5}$.

\footnotetext{
${ }^{1}$ Akta sejmiku kowieńskiego z lat 1733-1795, wyd. M. Jusupović, Warszawa 2019.

${ }^{2}$ M. J u s u pović, Prowincjonalna elita litewska $w$ XVIII wieku. Działalność polityczna rodziny Zabiełłów w latach 1733-1795, Warszawa 2014; e a d e m, Uczestnicy sejmików kowieńskich w czasach Augusta III i Stanisława Augusta Poniatowskiego - teoria i praktyka, „Rocznik Lituanistyczny” 2016, t. II, s. 127-142; e a d e m, Problem legalnego miejsca sejmików jako element rywalizacji politycznej: na przykładzie sejmików kowieńskich za panowania Stanisława Augusta, „Przegląd Wschodni" 2018, t. XIV, z. 4 (56), s. 841-854; e a d e m, Instrukcje kowieńskie $z$ lat 1733-1795 jako glos szlachty w sprawach powiatowych, „Klio” 2019, t. L, nr 3, s. 35-58.

${ }^{3}$ Akta sejmiku kowieńskiego..., s. 5-31.

${ }^{4}$ Podstawę źródłową stanowią: dokumenty sejmików lidzkich aktykowane w lidzkich księgach grodzkich: Nacyjanalny histaryczny archiu Biełarusi, Minsk [dalej: NGAB], fond 1722, wopis 1, sprawa 12, 13, 14; akta sejmikowe wiłkomierskie w: Lietuvos valstybès istorijos archyvas [dalej: LVIA], fondas SA, sygn. 1393213939 (księgi grodzkie) i 14209 (księga ziemska). Sygnatury w LVIA podaję według tradycyjnego układu, bez uwzględnienia dokonanej w ostatnim czasie numeracji fondu, w którym znajdują się księgi.

${ }^{5}$ R. Jurgaitis, Vilniaus seimelio veikla 1717-1795 m. Daktaro disertacija, Kaunas 2007 (dzięki uprzejmości Autora korzystałem z rozprawy w formacie .pdf); id e m, Nuo bajoriškosios savivaldos iki parlamentarizmo: Vilniaus seimelio veikla 1717-1795 m. Monografija, Vilnius 2016.
} 
Ważne dla tematu są też badania Adama Stankeviča. W 2013 r. przedstawił on rozprawę doktorską poświęconą Trybunałowi Głównemu Wielkiego Księstwa Litewskiego w drugiej połowie XVIII w. ${ }^{6}$ W pracy omówione zostały rugi deputackie $z$ lat 1779, 1780, 1785 i 1786, które dotyczyły m.in. rozstrzygnięcia rozdwojonych elekcji kowieńskich ${ }^{7}$. Pięć lat później dysertacja A. Stankeviča została opublikowana w Wilnie jako książka ${ }^{8}$.

Dla studiów porównawczych znaczenie mają także prace polskich historyków. Badania Stanisława Kościałkowskiego i jego uczennic sa bardzo istotne dla znajomości mechanizmów sejmikowych na Litwie w tym okresie, jednak niewiele uwagi poświęcaja zagadnieniom ustrojowym i organizacyjnym sejmików ${ }^{9}$. Ważna jest monografia Andrzeja B. Zakrzewskiego o sejmiku trockim. Dotyczy jednak całości jego dziejów, więc czasy Rady Nieustającej nie stały się przedmiotem szczegółowych rozważań ${ }^{10}$. Książki Andrzeja Rachuby o roli Litwy w systemie parlamentarnym Rzeczypospolitej i Diany Koniecznej o sejmiku brzeskolitewskim nie obejmuja czasów stanisławowskich ${ }^{11}$. Istotne sa także badania historyków białoruskich, zwłaszcza aktywnego na polu sejmikowym Andreja Macuka, którego publikacje dotyczą jednak przede wszystkim czasów saskich, zwłaszcza epoki Augusta III Wettyna ${ }^{12}$. Pozostaje

${ }^{6}$ A. Stankevič, Lietuvos Vyriausiojo Tribunolo veikla XVIII a. II pusèje: bajoriškosios teisès raiška. Dakataro disertacija, Vilnius 2013 [dysertacja doktorska $\mathrm{w}$ formacie .pdf].

7 A. Stankevič, op. cit., s. 96-98, 104-105.

8 W Polsce ukazała się recenzja tej pracy: K. Frejlich, (rec.) Adam Stankevič, Lietuvos Vyriausiojo Tribunolo veikla XVIII amžiaus antroje pusèje, Lietuvos istorijos institutas, Vilnius 2018, ss. 528, il., ISBN 978-609-8183-42-9, „Rocznik Lituanistyczny" 2018, t. IV, s. 172-175.

9 S. Kościałkow ski, Antoni Tyzenhauz. Podskarbi nadworny litewski, t. I-II, Londyn 1970-1971; K. Ad olphow a, Szlachta litewska wobec Zbioru Praw Andrzeja Zamoyskiego ( $w$ świetle litewskich instrukcyj poselskich z lat 1776, 1778, 1780, 1782), [w:] Ksiegga pamiątkowa Koła historyków Słuchaczy USB w Wilnie, Wilno 1933, s. 156-188; A. Kalenkiewiczówn a, Rozkład partii Tyzenhauza na tle sejmików litewskich, [w:] Księga pamiatkowa Koła..., s. 121-155.

10 A.B. Zakrzewski, Sejmiki Wielkiego Księstwa Litewskiego XVI-XVIII $w$. Ustrój i funkcjonowanie: sejmik trocki, Warszawa 2000 [dalej: A.B. Zakrzewski, Sejmik trocki...].

${ }^{11}$ A. Rachuba, Wielkie Księstwo Litewskie $w$ systemie parlamentarnym Rzeczypospolitej w latach 1569-1763, Warszawa 2002; D. Ko n i e cz n a, Ustrój i funkcjonowanie sejmiku brzesko-litewskiego w latach 1565-1763, Warszawa 2012.

12 Oprócz szeregu artykułów (do niektórych odwołuje się w dalszej części tekstu) wymienić należy monografię: A. Macuk, Baraćba mahnackich hrupowak u WKE (1717-1763 hh.), Minsk 2010. 
jeszcze kilka artykułów poświęconych zwykle zagadnieniom szczegółowym $^{13}$. Ostatnio historycy $z$ Litwy i Białorusi zainteresowali się parlamentaryzmem Wielkiego Księstwa w końcowych latach I Rzeczypospolitej (1791-1794). Badania te dotycza jednak życia sejmikowego funkcjonującego już w zmienionych ramach prawnych, co było spowodowane reformami z 1791 i 1793 r. ${ }^{14}$

Wielu materiałów do spostrzeżeń dostarczyły mi Akta sejmiku kowieńskiego. Ramy konstrukcyjne mojej analizy będą więc nawiązywać do wstępu autorstwa M. Jusupović oraz wydanych przez nią materiałów sejmikowych. Aby pokazać różnicę w dostępności do źródeł koronnych i litewskich, krótko przypomnę ostatnie osiągnięcia w zakresie edytorstwa akt sejmikowych. Dysponujemy już spora liczbą wydawnictw odnoszących się do sejmików koronnych. Ich liczba w XXI w. poważnie wzrosła dzięki wysiłkom Michała Zwierzykowskiego i zespołów pracujących pod jego kierownictwem nad aktami sejmików wielkopolskich ${ }^{15}$, a także dzięki pracom historyków lubelskich z Henrykiem Gmiterkiem na czele (sejmiki

${ }^{13}$ V. Buben, Rozdwojone wybory urzędników ziemskich na sejmiku elekcyjnym województwa nowogródzkiego 5 lutego 1777 roku, „Zeszyty Naukowe Uniwersytetu Jagiellońskiego. Prace Historyczne” 2006, z. 133, s. 55-71; W. Fili p czak, Ekonomie litewskie $w$ polityce sejmikowej Stanisława Augusta po upadku Antoniego Tyzenhauza (1780-1783), „Przegląd Nauk Historycznych” 2006, R. V, nr 1 (9), s. 235-276. Nie zdążyłem już wykorzystać artykułu o sejmikach mozyrskich: D. Rolnik, Sejmiki poselskie mozyrskie w latach 1778-1786 i ich reprezentanci na sejmach Rzeczypospolitej, [w:] Parłamientaryzm u Wialikim Kniastwie Litouskim u XVIII stahoddzi, składalniki A. Macuk, R. Jurgaitis (Aktualnyje problemy istorii i kultury. Zbornik nawukowych artykułau, wypusk 2), Minsk 2020, s. 258-280, który ukazał się po napisaniu mojego tekstu. Bardziej syntetyczny charakter ma artykuł: A.B. Zakrzewski, Sejmiki Wielkiego Księstwa Litewskiego epoki stanisławowskiej (do 1788 r.). Zmiany w ustroju i funkcjonowaniu, [w:] Ziemie północne Rzeczypospolitej polsko-litewskiej $w$ dobie rozbiorowej 1772-1815, red. M. Biskup, Warszawa-Torun 1996, s. 59-66.

${ }^{14}$ W tomie Parłamientaryzm u Wialikim Kniastwie Litouskim..., który ukazał się już po przygotowaniu tego tekstu, znajduja się artykuły Ramunè Šmigels ky tè-Stukienè o sejmikach województwa grodzieńskiego w lutym 1794 r. i Vadzima Anipiarkou o powiecie słuczoreskim w latach 1791-1792.

${ }_{15}$ Akta sejmikowe województw poznańskiego i kaliskiego. Lata 1696-1732, wyd. M. Zwierzykowski, Poznań 2008; Akta sejmikowe województw poznańskiego i kaliskiego. Lata 1733-1763, wyd. M. Zwierzykowski, Poznań 2015; Akta sejmikowe województw poznańskiego i kaliskiego. Lata 1668-1675, wyd. M. Zwierzykowski, R. Kołodziej, A. Kamieński, Poznań 2018; Akta sejmikowe województw poznańskiego i kaliskiego. Lata 1676-1695, wyd. M. Zwierzykowski, R. Kołodziej, A. Kamieński, Poznań 2018. 
chełmskie i lubelskie) ${ }^{16}$. Ukazały się również akta egzulanckiego sejmiku podolskiego opracowane przez Jarosława Stolickiego oraz opublikowane przez zespół Mirosława Nagielskiego lauda województwa rawskiego ${ }^{17}$. Znacznie gorzej wygląda sytuacja, jeśli chodzi o sejmiki z Wielkiego Księstwa Litewskiego. Na uwagę zasługuje wydawnictwo litewskich badaczy: Robertasa Jurgaitisa, Adama Stankeviča i Asty Verbickienè, które zawiera litewskie instrukcje poselskie na Sejm Czteroletni ${ }^{18}$. Prowadzone sa prace nad edycja akt sejmików nowogródzkich (zespół kierowany przez A. Rachubę) i wileńskich (zespół Tomasza Kempy) ${ }^{19}$, które nie zostały dotychczas opublikowane. Ze względu na specyfikę sejmików litewskich w wielu sprawach badacze mają ograniczone możliwości wykorzystania koronnych akt sejmikowych jako materiału porównawczego. Jednak odwołanie się do praktyki sejmików koronnych wydaje mi się konieczne do zrozumienia pewnych cech specyficznych dla litewskiej kultury parlamentarnej.

We wstępie do Akt sejmiku kowieńskiego omówione zostały dzieje polityczne tego powiatu w latach 1733-1794. Autorka mogła tu wykorzystać swoje dotychczasowe doświadczenia badawcze, związane zwłaszcza $z$ monografią o politycznej aktywności Zabiełłów w czasach Augusta III i Stanisława Augusta ${ }^{20}$. Tekst M. Jusupović dotyczy okresu przeszło 60 lat, więc trudno się dziwić, że prezentacja poszczególnych kampanii sejmikowych ma zwięzły charakter ${ }^{21}$. Autorka pominęła (lub tylko zasygnalizowała) kilka interesujaccych

16 Akta sejmikowe ziemi chełmskiej 1572-1668, oprac. W. Bondyra, H. Gmiterek, J. Ternes, Lublin 2013; Akta sejmikowe województwa lubelskiego 1572-1632, oprac. H. Gmiterek, Lublin 2016.

17 Akta sejmiku podolskiego in hostico 1672-1698, oprac. J. Stolicki, Kraków 2002; Lauda ziemi rawskiej i województwa rawskiego 1583-1793, red. M. Nagielski, oprac. M. Bąk, M. Borkowski, K. Chłapowski, A. Haratym, T. Płóciennik, Ł. Przybyłek, E. Walczuk, Warszawa 2017.

18 Lietuvos Dzidžiosios Kunigaikštystès seimeliu instrukcijos (1788-1790), parengè R. Jurgaitis, A. Stankevič, A. Verbickienè, Vilnius 2015. Por. też W. Filipczak, Instrukcje dla posłów z Wielkiego Księstwa Litewskiego na Sejm Wielki. Uwagi na temat nowego litewskiego wydawnictwa źródłowego (rec.: Lietuvos Dzidžiosios Kunigaikštystès seimeliu instrukcijos [1788-1790], parengé Robertas Jurgaitis, Adam Stankevič, Asta Verbickiene, UAB „Vitae Litera”, Vilnius 2015, ss. 436), „Przegląd Nauk Historycznych” 2017, R. XVI, nr 2, s. 302-314.

19 Akta sejmiku kowieńskiego..., s. 7.

${ }^{20}$ M. Ju s u povi ć, Prowincjonalna elita litewska..., s. 279-321.

${ }^{21}$ Akta sejmiku kowieńskiego..., s. 7-18. 
wydarzeń rozgrywających się wokół politycznych sporów w powiecie kowieńskim, do których powrócę w dalszej części artykułu.

Wiele wiadomości o aktywności parlamentarnej szlachty kowieńskiej dostarcza Zestawienie sejmików kowieńskich oraz wydanych przez nie akt ${ }^{22}$. Mamy w nim zebrane przez M. Jusupović w formie tabel wiadomości o układzie źródeł według roku powstania i typu dokumentu (instrukcje, kredensy, sufragia, lauda, manifesty, listy królewskie lub inne listy na sejmiki itd.) ${ }^{23}$. We wprowadzeniu do zestawienia zabrakło jednak chociażby wzmianki o koncepcji sejmiku - stworzonej przez Adama Lityńskiego - jako jednolitej instytucji prawnej ${ }^{24}$. Zyskała ona dość powszechną akceptację historyków zajmujących się problematyka sejmikową ${ }^{25}$. Wprawdzie została ona sformułowana na podstawie źródeł pochodzących $z$ Korony, ale jej założenia zaakceptował Andrzej B. Zakrzewski, wybitny znawca parlamentaryzmu litewskiego ${ }^{26}$. Posługiwał się nią także, choć zachowując pewien dystans, A. Rachuba - kolejny znakomity badacz tej tematyki ${ }^{27}$. Jak zauważył ten historyk, koncepcja Lityńskiego w odniesieniu do początków litewskich sejmików nie przystaje do obowiąujących w Wielkim Księstwie rozwiązań prawnych $^{28}$. Uważam jednak, że "wielofunkcyjne” sejmiki gromniczne w omawianym przeze mnie okresie doskonale do tej teorii pasuja.

Analizując dane liczbowe dotyczące sejmików kowieńskich (było ich 116, ale dostępne są źródła dotyczące 97), widzimy dominację sejmików deputackich. Obradowały one 59 razy (powinny zbierać się co roku, wyjątek stanowiły okresy bezkrólewia i czasy konfederacji generalnych). Odbyło się także 28 zgromadzeń przedsejmowych $^{29}$. Zwraca uwagę to, że nieliczne były w Kownie sejmiki gospodarskie, choć również one powinny zbierać się corocznie (dzień po wyborze deputata). Poświadczonych źródłowo obrad jest tylko 13, choć M. Jusupović słusznie zakłada, że mogło być ich więcej. Świadczy o tym sytuacja $z 1782$ r., kiedy nie ma żadnej

22 Ibidem, s. 18-27.

${ }^{23}$ Ibidem, s. 22-24.

${ }^{24}$ A. Lityń s ki, Z problematyki klasyfikacji sejmików ziemskich, „Prace Naukowe Uniwersytetu Śląskiego w Katowicach” 1969, nr 5, Prace Prawnicze 1, s. 89-105.

${ }_{25}$ M. Zwi erzykow ski, Samorzad sejmikowy województw poznańskiego i kaliskiego w latach 1696-1732, Poznań 2010, s. 21.

26 A.B. Zakrzewski, Sejmik trocki..., s. 23.

27 A. Rachuba, op. cit., s. 9.

${ }^{28}$ Ibidem, s. 72-73.

${ }^{29}$ Akta sejmiku kowieńskiego..., s. 18. 
uchwały, choć o sejmiku gospodarskim jest wzmianka w kredensie dla deputatów na Trybunał Litewski podpisanym 5 lutego ${ }^{30}$.

Powyższe zjawisko nie może dziwić, gdyż traktowanie obrad gospodarskich jako nieobligatoryjnych stwierdzili już badacze sejmików koronnych. Jerzy Włodarczyk zauważył, że w województwie łęczyckim do obrad tych przystępowano czasami jeszcze w dniu wyboru deputata, bez elekcji nowego marszałka czy spisania odrębnego laudum ${ }^{31}$. Można dodać, że w latach osiemdziesiątych XVIII w. w Łęczycy uchwały gospodarskie podejmowano nie tylko na sejmikach deputackich (1785), lecz także na poselskich $(1784)^{32}$. Podobne sytuacje (w stosunku do zgromadzeń deputackich) odnotował Adam Lityński w odniesieniu do sejmików województwa płockiego. Badacz ten stwierdził: „Nie traktowano, widać, zebrania nazajutrz po deputackim jako obligatoryjnego, jeśli brakło dlań materii" 33 . Z monografii Waldemara Bednaruka wynika, że w latach 1764-1794 w województwie lubelskim obradowało 12 sejmików gospodarskich. W liczbie tej sa dwa konkurencyjne sejmiki w lipcu 1776 r., po rozdwojeniu zgromadzenia przedsejmowego, a także dwukrotne obrady boni ordinis odbywające się w dniu wyboru deputata $(1780,1785)^{34}$. Zjawisko zmniejszania się aktywności sejmików w sprawach samorządowych widoczne jest również w prowincji wielkopolskiej w latach osiemdziesiatych XVIII w. O ile w okresie 1777-1780 sejmiki gospodarskie w Środzie zebrały się cztery razy, o tyle już dla okresu 1781-1786 nie ma żadnej uchwały boni ordinis ${ }^{35}$. Podobna była sytuacja na Kujawach, gdzie po sejmiku w 1777 r. nie ma żadnego takiego zgromadzenia do 1786 r., a uchwały o charakterze samorzadowym i ekonomicznym podejmowano w czasie innych obrad. W 1779 r. był to sejmik deputacki, rok później przedsejmowy ${ }^{36}$. W województwie sieradzkim dla lat 1777-1780 nie są znane uchwały gospodarskie, choć już

30 Ibidem, s. 19, 345-346.

${ }^{31}$ J. Włodarczyk, Sejmiki łęczyckie, Łódź 1973, s. 94.

${ }^{32}$ W. Filipczak, Życie sejmikowe prowincji wielkopolskiej $w$ latach 17801786, Łódź 2012, s. 493.

${ }^{33}$ A. Lityński, Sejmiki województwa płockiego przed $i w$ czasie Sejmu Czteroletniego. $Z$ badań nad organizacja i funkcjonowaniem, [w:] W dwusetna rocznice wolnego Sejmu. Ludzie - państwo - prawo czasów Sejmu Czteroletniego, red. A. Lityński, Katowice 1988, s. 80.

${ }^{34}$ W. Bed naruk, Sejmiki lubelskie w okresie stanisławowskim (1764-1794), Lublin 2011, s. 80-82, 403-423.

${ }^{35}$ W. Filipczak, Życie sejmikowe..., s. 298-299.

${ }^{36}$ Ibidem, s. 558-559. 
w okresie 1781-1788 zebrały się cztery takie sejmiki (w Piotrkowie) ${ }^{37}$. Podobna do wielkopolskiej była sytuacja w województwie płockim. W Raciaż̇u w latach 1775-1778 sejmik gospodarski zebrał się trzy razy, później zaś (lata 1779-1787) nie ma wiadomości, żeby odbyło się odrębne zgromadzenie tego rodzaju ${ }^{38}$.

Jak się wydaje, analogicznie wyglądała sytuacja w Wielkim Księstwie Litewskim. Podobnie jak w Koronie, również tutaj na spadek znaczenia obrad gospodarskich wpłynać mogło pozbawienie sejmików (w latach 1766-1768) uprawnień podatkowych i finansowych $^{39}$. O zasadności takiej tezy może świadczyć częstotliwość obrad wileńskich sejmików gospodarskich, które w latach 17331794 zbierały się 23 razy $^{40}$ (z przyczyn porównawczych ograniczam statystykę do okresu zbadanego przez M. Jusupović). Na okres 1733-1763 przypada 14 zgromadzeń wileńskich, a w latach 17641768 odbyły się dwa sejmiki $(1765,1768)$. Po 1768 r. na obrady gospodarskie w Wilnie zebrano się więc siedem razy. Liczba ta wymaga jednak komentarza, gdyż rozkład zgromadzeń był bardzo nierównomierny. W latach 1769-1772 sejmiki gospodarskie odbywały się corocznie ${ }^{41}$. Po pierwszym rozbiorze szlachta zebrała się w Wilnie na zgromadzeniach gospodarskich tylko trzy razy (1785, $1787,1792)^{42}$. Sejmik trocki, jak wynika $z$ przykładów przytoczonych przez A.B. Zakrzewskiego, w okresie od pierwszego rozbioru do Konstytucji 3 maja zbierał się na obradach gospodarskich przynajmniej cztery razy $(1773,1775,1786,1791)^{43}$.

Jak na tym tle wypada powiat kowieński? Istnieja tylko trzy wiadomości o sejmikach w czasach Augusta III Wettyna (1743, $1744,1761)$. Kolejne trzy zgromadzenia tego rodzaju zebrały się w początkach panowania Stanisława Augusta $(1766,1767,1768)^{44}$.

37 W latach: 1781, 1785, 1787, 1788. Ibidem, s. 425-427, 436-437, 441.

${ }^{38}$ W. Filipczak, Sejmiki województwa płockiego 1780-1786, „Przegląd Nauk Historycznych" 2009, R. VIII, nr 2, s. 53-54.

39 A.B. Zakrzewski, Sejmik trocki..., s. 210-211; M. Zwierzykowski, Komisja Skarbowa Poznańska. $Z$ dziejów sejmikowej administracji $i$ sądownictwa skarbowego w Wielkopolsce w XVII i XVIII wieku, Poznań 2003, s. 247-248, 253.

${ }^{40}$ R. Jurgaitis, Nuo bajoriškosios..., s. 367-402. Sejmiki te obradowały w latach: 1733, 1734, 1737-1742 (co rok), 1744, 1748, 1756, 1757, 1759, 1760, 1764, 1765, 1768-1772 (co rok), 1785, 1787, 1792.

41 Ibidem, s. 389-391.

42 Ibidem, s. 397-399. Na temat politycznych aspektów sejmiku wileńskiego w 1792 r. por. W. Szczygielski, Referendum trzeciomajowe. Sejmiki lutowe 1792 roku, Łódź 1994, s. 300-301.

43 A.B. Zakrzewski, Sejmik trocki..., s. 183-184.

${ }^{44}$ Akta sejmiku kowieńskiego..., s. 69-71, 136, 188-189, 212-213, 225-226. 
W Kownie, w porównaniu z Wilnem, z okresu po 1768 r. pozostało nieco mniej - sześć akt sejmików gospodarskich (nie było ich w 1782 r.). Do ciekawych wniosków prowadzi jednak analiza ich rozkładu chronologicznego. Pierwsze dwa zgromadzenia boni ordinis zebrały się jeszcze w dobie konfederacji barskiej $(1771,1772)^{45}$. Kolejne zachowane akta sejmiku gospodarskiego pochodzą dopiero z 1785 r., a kolejne trzy z czasów Sejmu Czteroletniego (1790, $1791,1792)^{46}$. Oznacza to, że $z$ okresu od pierwszego rozbioru do 1784 r. nie zachowały się żadne uchwały gospodarskie (podobna sytuacja była w Wilnie). Nie wynika jednak $z$ tego, że obrady boni ordinis nie odbywały się w tym czasie. Sa powody, by sądzić, że mogło być inaczej, za czym przemawia uniwersał Stanisława Augusta $z 20$ czerwca 1775 r. w sprawie wyboru na sejmikach komisarzy prowiantowych (dostawy żywności i furażu dla wojsk rosyjskich) ${ }^{47}$ oraz wspomniana wzmianka o obradach gospodarskich w kredensie deputackim z $1782 \mathrm{r}$. Nie bez znaczenia był powód, dla którego pojawiła się uchwała zgromadzenia boni ordinis w lutym $1785 \mathrm{r}$. Było nim wystawienie kredensu i instrukcji dla delegatów powiatu kowieńskiego do arcybiskupa gnieźnieńskiego Michała Poniatowskiego $^{48}$. Mieli oni złożyć powinszowanie i oświadczyć rekognicję nowemu prymasowi, który uzyskał nominację od swego królewskiego brata w październiku 1784 r. ${ }^{49} \mathrm{~W}$ lipcu 1785 r., przy okazji odbywających się w połowie miesiąca sejmików deputackich i gospodarskich, podobne poselstwa wysłało także wiele sejmików koronnych ${ }^{50}$. Można postawić hipotezę, że jeśli na Litwie w czasach Rady Nieustającej odbywały się obrady gospodarskie, ich uchwały nie zawsze były wpisywane do ksiag sadowych. Ze względu na utratę uprawnień finansowych przez sejmik prawdopodobnie nie widziano takiej potrzeby.

45 Ibidem, s. 243, 245-246.

46 Ibidem, s. 389-390, 446-448, 456-457, 497-499.

47 Ibidem, s. 254. Z nieznanych powodów w tytule dokumentu podana jest inna data (21 VI 1775 r.) niż w tekście uniwersału.

48 Ibidem, s. 389-392.

49 Król Stanisław August nominował M. Poniatowskiego na arcybiskupa gnieźnieńskiego na sesji Rady Nieustającej 2 X 1784 r. Por. Protokół potoczny Rady Nieustającej z 2 X 1784 r., Archiwum Główne Akt Dawnych w Warszawie [dalej: AGAD], tzw. Metryka Litewska, [dalej: ML], dział VII, sygn. 52, k. 91v. Por. też Z. Zielińska, Poniatowski Michał Jerzy, [w:] Polski słownik biograficzny [dalej: $P S B]$, t. XXVII, Wrocław 1983, s. 457; R. But te rw i ck, Polska rewolucja a Kościół katolicki 1788-1792, przekł. M. Ugniewski, Kraków 2012, s. 224.

${ }^{50}$ W. Filipczak, Życie sejmikowe..., s. 140, 142. 
Potwierdzeniem powyższego poglądu mogą być dane $z$ lat 17761786 dotyczące sejmików powiatów wiłkomierskigo i lidzkiego (wchodziły one w skład województwa wileńskiego ${ }^{51}$ ). W Wiłkomierzu, jak wynika $z$ postanowień sejmiku gromnicznego $z$ 5-7 lutego 1781 r., 6 lutego (dzień po wyborze deputata) zebrano się na obrady boni ordinis ${ }^{52}$. Kolejny sejmik gospodarski, który tym razem pozostawił po sobie uchwałe w aktach sądowych, odbył się 4 lutego 1783 r. Miejscowa szlachta uchwaliła wówczas laudum dotyczące wysłania do Warszawy, jako delegata sejmiku, sędziego-prezydenta sądu ziemskiego Józefa Kuszelewskiego ${ }^{53}$. Miał on czuwać nad uzyskaniem od Rady Nieustającej odpowiedzi na memoriał, który ziemianie wiłkomierscy złożyli w sprawie nadużyć przy pobieraniu opłat w komorach celnych (narzuconych przez Komisję Skarbu Litewskiego), co utrudniało handel z Ryga.. Uczestnicy sejmiku uchwalili osobny „instrument” dla delegata (jego treść nie jest zna$n \mathrm{a}^{54}$ ), a także przewidzieli rekompensatę finansowa za poniesione koszty. Miała ono pochodzić $z$ dodatkowych 15 groszy pobieranych $z$ każdego dymu w powiecie (dotyczyło to raty marcowej w 1783 r.), który był zobowiązany do płacenia podymnego ${ }^{55}$. W tym wypadku, podobnie jak w Kownie w 1785 r., chodziło o nadzwyczajne działania miejscowej szlachty, które nie mieściły się w tematyce spraw lokalnych i samorządowych. Należy też zauważyć, że sejmik podjął uchwałę podatkowa (wbrew prawu z 1768 r. ${ }^{56}$ ), co było zapewne kolejnym powodem, dla którego laudum zostało wpisane do ksiag grodzkich.

${ }^{51}$ Powiat lidzki wszedł ostatecznie w skład województwa wileńskiego około 1568 r. Por. Urzędnicy Wielkiego Księstwa Litewskiego. Spisy, t. I (Województwo wileńskie XIV-XVIII wiek), red. A. Rachuba, oprac. H. Lulewicz, A. Rachuba, P.P. Romaniuk, współpraca U. Jemialianczuk, A. Macuk, Warszawa 2004, s. 16-17.

${ }^{52}$ Instrument uniwersalny elekcji urzędników, Wiłkomierz 7 II 1781 (wpis do ksiag grodzkich wiłkomierskich 8 II), LVIA, fondas SA, sygn. 13934, k. 452-453.

${ }^{53}$ Laudum powiatu wiłkomierskiego dla J. Kuszelewskiego, Wiłkomierz 4 II 1783, LVIA, fondas SA, sygn. 13936, k. 36-36v. Szerzej temat omawiam w artykule: W. Fili pczak, Sejmiki powiatu wiłkomierskiego w latach 1781-1784, „Zapiski Historyczne" 2020, t. LXXXV, z. 2, s. 67-93.

${ }^{54} \mathrm{~W}$ odniesieniu do czasów wcześniejszych D. Konieczna (op. cit., s. 77) zauważyła, że nie zawsze w księgach grodzkich brzeskolitewskich sa oblaty instrukcji dla posłów wysyłanych przez sejmiki gospodarskie lub relacyjne, choć wzmiankuje się o nich w uchwałach.

55 Laudum dla J. Kuszelewskiego, Wiłkomierz 4 II 1783, LVIA, fondas SA, sygn. 13936, k. 36v-37.

${ }^{56}$ Volumina legum [dalej: Vol. leg.], t. VII, wyd. J. Ohryzko, Petersburg 1860, s. 294 (ustawa: Porzadek sejmikowania); A.B. Zakrzewski, Sejmik trocki..., s. 211. 
Odmienną sytuację, podobną do praktyki kowieńskiej z 1782 r., mamy w powiecie lidzkim. W czasie obrad gromnicznych w lutym 1784 r. w Lidzie zebrał się także sejmik boni ordinis. Uchwała tego zgromadzenia nie została wniesiona do ksiag grodzkich, ale wzmianka na temat obrad gospodarskich znalazła się w dwóch kredensach dla urzędników lidzkich (podkomorzego i marszałka powiatowego) wybranych na sejmikach elekcyjnych zakończonych 11 lutego 1784 r. ${ }^{57}$ Zgromadzenie gospodarskie obradowało po elekcji deputatów na Trybunał Litewski (odbyła się 9 lutego 1784 r.), być może jeszcze tego samego dnia ${ }^{58}$. W świetle powyższych przykładów można zaryzykować tezę, że przynajmniej na części sejmików litewskich funkcjonowała praktyka, że uchwały boni ordinis wpisywano do ksiagg sądowych tylko w sytuacji, kiedy dotyczyły szczególnie istotnych spraw.

Według M. Jusupović w Kownie od 1733 r. odbył się tylko jeden sejmik relacyjny. Zebrał się on 23 lipca $1764 \mathrm{r} .{ }^{59}$, miesiąc po zakończeniu zgromadzenia konwokacyjnego. Był on jednocześnie sejmikiem przedelekcyjnym. Takie połączenie obrad wynikało $z$ ustawy wydanej przez sejm konwokacyjny ${ }^{60}$. Komentując brak dokumentów uchwalonych przez inne sejmiki relacyjne, M. Jusupović stwierdziła, że „można mieć wątpliwości, czy w tym czasie one nie zanikały" ${ }^{\text {. W }}$ Wkazała także, powołując się na badania Andrzeja B. Zakrzewskiego, że podobna sytuacja występowała w odniesieniu do sejmiku trockiego ${ }^{62}$. Według M. Jusupović obrady relacyjne $z$ zasady były łączone $z$ innymi sejmikami. Przywołała w tej sprawie ustalenia zawarte w monografii Waldemara Bednaruka ${ }^{63}$. Autorka wstępu do Akt sejmiku kowieńskiego stwierdziła też, że sejmiki

57 Kredens na podkomorstwo dla Tadeusza Narbutta, Lida 11 II 1784 (aktykacja 12 II 1784), NGAB, fond 1722, wopis 1, sprawa 13, k. 631-631v; Kredens na marszałkostwo lidzkie dla Franciszka A. Alexandrowicza, Lida 11 II 1784 (aktykacja 13 II 1784), NGAB, fond 1722, wopis 1, sprawa 13, k. 636-636v.

58 Kredens na podkomorstwo dla T. Narbutta, Lida 11 II 1784, NGAB, fond 1722, wopis 1, sprawa 13, k. 631.

59 Akta sejmiku kowieńskiego..., s. 19, 164-165.

60 Vol. leg., t. VII, s. 10 (ustawa: Sejmiki relationis). Na temat postanowień sejmiku przedelekcyjnego powiatu rzeczyckiego por. A.U. M acuk, Reczyckija pawiatowyja sojmiki u bieskaraleuie 1764 h., „Izwiestija Gomielskogo gosudarstwiennogo uniwiersitieta imieni F. Skoriny" 2018, nr 4 (109), s. 50-51.

${ }^{61}$ Akta sejmiku kowieńskiego..., s. 19.

62 Ibidem, s. 19-20. Por. A.B. Zakrzewski, Sejmik trocki.., s. 148.

63 Akta sejmiku kowieńskiego..., s. 19; W. Bednaruk, op. cit., s. 83-84. 
relacyjne mogły odbywać się częściej, „ale nie wydawano na nich żadnych aktów prawnych". Na potwierdzenie tej tezy przytoczony został sejmik relacyjny $z$ lutego 1779 r., który dokumentów nie pozostawił, choć wspomniano o nim w remanifeście $z 12$ lutego 1779 r. ${ }^{64}$ Dodam, że o złożeniu na sejmiku gospodarskim relacji $z$ sejmu przez Adama Kozakowskiego wiemy też $z$ jego listu z 12 lutego 1779 r. ${ }^{65}$

Przytoczone ustalenia nie wystarczają do wyjaśnienia braku uchwał sejmików relacyjnych. W odniesieniu do czasów Augusta III można założyć, że duże znaczenie miało notoryczne (od 1738 r.) niedochodzenie sejmów. Za taką tezą świadczyć może sytuacja sejmiku wileńskiego od 1733 r. Przez 61 lat (1733-1794) R. Jurgaitis odnotował tylko dwa zgromadzenia relacyjne. Sejmiki te, będące jednocześnie zgromadzeniami pokonwokacyjnymi i przedelekcyjnymi, obradowały w lipcu 1733 r. i w lipcu 1764 r. ${ }^{66}$ Bardziej skomplikowane jest wytłumaczenie zaniku sejmików relacyjnych w czasach panowania Stanisława Augusta. Zebranie się sejmików relacyjnych przewidziały, co zauważył litewski historyk, jeszcze ustawy sejmu koronacyjnego w 1764 r. (ich termin ustalono „na sejmiki pogromniczne" w 1765 r.) i zwyczajnego w 1766 r. (na Litwie miano zebrać się „nazajutrz po sejmikach gromnicznych gospodarskich" w 1767 r.) ${ }^{67}$. Jednak przez kolejne kilkanaście lat panowania tego monarchy (do 1778 r.) nie było prawnych podstaw do ich zbierania się, co było zapewne świadoma polityka dworu. Brakuje uniwersałów królewskich zwołujących sejmiki relacyjne; milczą na ich temat także konstytucje sejmowe. Jedynym znanym mi wyjątkiem jest uniwersal Stanisława Augusta z 6 kwietnia 1768 r., na podstawie którego zwołane zostały przez wojewodów sejmiki posej-

${ }^{64}$ Akta sejmiku kowieńskiego..., s. 19, 300.

65 A. Kozakowski do NN, Kowno 12 II 1779, AGAD, Zbiór Popielów [dalej: ZP], sygn. 111, k. 42; W. Filipczak, Sejm 1778 roku, Warszawa 2000, s. 339. W książce nieścisła jest informacja, że relację złożono na sejmiku deputackim.

${ }^{66}$ R. Jurgaitis, Nuo bajoriškosios..., s. 368, 385; i d e m, Funkcjonowanie sejmiku wileńskiego $w$ latach 1717-1795: między szlacheckim parlamentaryzmem a samorzadem, [w:] Praktyka życia publicznego w Rzeczypospolitej Obojga Narodów w XVI-XVIII wieku, red. U. Augustyniak, A.B. Zakrzewski, Warszawa 2010, s. 47.

67 Vol. leg., t. VII, s. 186 (ustawa: Sejmiki relacyjne w W. Ks. Lit.), 221 (ustawa Deklaracja sejmików relacyjnych...); R. Ju rgaitis, Vilniaus seimelio..., s. 47; id em, Funkcjonowanie sejmiku..., s. 43. 
mowe w Prusach Królewskich ${ }^{68}$. Obrady te były zbojkotowane przez szlachtę znajdująca się pod wpływem konfederacji barskiej ${ }^{69}$.

Nie oznacza to jednak, że w latach $1768-1778$ całkowicie poniechano zwyczaju składania relacji $z$ obrad sejmu, o czym świadczy przykład relacji z sejmu rozbiorowego złożonej przez Feliksa Oraczewskiego na sejmiku poselskim województwa krakowskiego w Proszowicach (15 lipca 1776 r. $)^{70}$. Na sejmiku trockim w lutym 1777 r. została przedstawiona relacja $z$ sejmu, który odbył się w roku poprzednim ${ }^{71}$.

Istotna zmiana nastapiła w wyniku decyzji sejmu z 1778 r. Parlament przyjął wówczas ustawę pt. Sejmiki relationis dla Korony i Księstwa Litewskiego ${ }^{72}$. Mówiono w niej wprawdzie o przywróceniu sejmików relacyjnych, jednak ustalono, że mają się one odbywać na pierwszych obradach po zakończeniu sejmu ${ }^{73}$. W praktyce oznaczało to, że nie były to odrębne sejmiki relacyjne, lecz relacje poselskie składane na innych sejmikach. Tak też wyglądała praktyczna realizacja tej ustawy w Koronie. Jeśli relację złożono, najczęściej okazją do niej był lipcowy sejmik deputacki (inaczej było w województwie mazowieckim), ewentualnie obrady poświęcone wyborowi kandydatów na urzędy - w sytuacji kiedy w okresie między końcem sejmu a połową lipca szlachta zebrała się na sejmiku elekcyjnym ${ }^{74}$.

W tym kontekście nie może dziwić, że w czasach Stanisława Augusta pierwsza wzmianka o sejmiku relacyjnym w Kownie odnosi

68 Uniwersał Stanisława Augusta, Warszawa 6 IV 1768, oraz uniwersał wojewody pomorskiego Jerzego Flemminga, Skarszewy 21 IV 1768, Archiwum Państwowe w Gdańsku, sygn. 300, 29/231, k. 85, 111; Uniwersał wojewody chełmińskiego Franciszka S. Czapskiego, Kowalewo 22 IV 1768, Archiwum Państwowe w Toruniu, Katalog II, dział VII, sygn. 60, k. 6.

69 S. Achremczyk, Sejmik generalny Prus Królewskich 1526-1772, Olsztyn 2016, s. 42 .

${ }^{70}$ [F. O raczews ki], Relacya $z$ poselstwa odprawionego na seymie extraordynaryinym warszawskim. zaczętym roku... 1773 [...] na seymiku poselskim $w$ roku 1776 dnia 15 julij [...] w Proszowicach, [b.m. i d.].

${ }^{71}$ A.B. Zakrzewski, Sejmik trocki..., s. 148.

${ }^{72}$ W. Filipczak, Sejm 1778 roku, s. 306-308.

73 Vol. leg., t. VIII, s. 580 (ustawa: Sejmiki relationis dla Korony i Księstwa Litewskiego).

${ }^{74}$ W. Fili pczak, Sejm 1778 roku, s. 337; id e m, Sejmiki ziemi czerskiej 17801786, „Przeglad Nauk Historycznych” 2010, R. IX, nr 1, s. 161-163; id e m, Życie sejmikowe..., s. 449, 510, 567-568; W. Bednaruk, op. cit., s. 83. 
się do 11 lutego 1779 r. Remanifest szlachty powiatu kowieńskiego, w którym jest wzmianka o sejmikach relacyjnych, nosi date 12 lutego 1779 r. Jednak $z$ treści dokumentu można wnosić, że relację złożono dzień wcześniej, przy okazji sejmiku gospodarskiego $^{75}$. Nasuwa się wattpliwość, dlaczego w kolejnych latach nieparzystych nie pojawiły się dokumenty lub informacje o tego rodzaju zgromadzeniach. Spróbujmy przeanalizować sytuację, wykorzystując informacje dotyczące innych sejmików litewskich. $Z$ dysertacji R. Jurgaitisa wynika, że wspomniany wileński sejmik pokonowokacyjny (i przedelekcyjny) z 1764 r. był w latach 1764-1795 jedyna sesja sejmikowa sklasyfikowana jako relacyjna ${ }^{76}$. Także w powiecie lidzkim w latach 1776-1786 brakuje w aktach sejmikowych wzmianek o relacjach $z$ sejmu ${ }^{77}$. Inaczej sytuacja wygladała w powiecie wiłkomierskim. W uchwale sejmiku elekcyjnego z 8 lutego 1781 r. zostało napisane, że 6 lutego, na sejmiku boni ordinis wysłuchana została relacja „o czynnościach sejmu ostatniego", która złożyli pisarz litewski Benedykt Morykoni i chorąży wiłkomierski Ignacy Kościałkowski ${ }^{78}$. Cztery lata później, 8 lutego 1785 r., jak pisano w kredensach dla deputatów, wykonali oni przysięgę nazajutrz po wyborze, na sejmiku relacyjnym ${ }^{79}$. Częściej wzmianki o relacjach $z$ sejmu pojawiały się $w$ aktach sejmików trockich. Andrzej B. Zakrzewski wspomina o nich w latach: 1781, 1783 i 1787 . W Trokach także nie ma jednak mowy o odrębnych sejmikach relacyjnych. Przynajmniej dwukrotnie relację złożono przed rozpoczęciem obrad gospodarskich ${ }^{80}$.

Brak dokumentów sejmików relacyjnych w wielu powiatach litewskich w czasach Rady Nieustającej wynika zapewne $z$ tego, że takich uchwał nie było. Podobnie jak w Koronie, na Litwie zgodnie $z$ ustaleniami ustawy z $1778 \mathrm{r}$. ograniczano się do prezentacji relacji poselskich (ewentualnie do dyskusji nad nimi, ale na to nie

${ }^{75}$ Akta sejmiku kowieńskiego..., s. 300.

76 R. Jurgaitis, Vilniaus seimelio..., s. 82.

77 Podstawą źródłową jest 25 dokumentów uchwalonych przez sejmiki lidzkie (jako jeden dokument liczę dwa nieróżniące się treścią kredensy dla deputatów na Trybunał Litewski, które były wydane w tym samym dniu) aktykowane w lidzkich księgach grodzkich (NGAB, fond 1722, wopis 1, sprawa 12, 13, 14).

78 Instrument „uniwersalny” elekcji urzędników, Wiłkomierz 8 II 1781, LVIA, fondas SA, sygn. 13934, k. 452v.

${ }^{79}$ Kredensy dla deputatów, Wiłkomierz 8 II 1785 (oblata 9 II), LVIA, fondas SA, sygn. 13938, k. 25v, 29v. Szerzej na temat sejmiku: W. Filipczak, Sejmiki powiatu...

${ }^{80}$ A.B. Zakrzewski, Sejmik trocki..., s. $148-149$. 
ma dowodów). Jeśli nawet w źródłach pojawia się sformułowanie o sejmikach relacyjnych (Kowno 1779, Wiłkomierz 1785), stanowi to raczej nawiazanie do nomenklatury użytej we wspomnianej konstytucji. Relacje odbywały się zazwyczaj w czasie między obradami deputackimi a gospodarskimi. Sytuacja prawna zmieniła się podczas Sejmu Wielkiego, kiedy w 1791 r. prawo o sejmikach przywróciło obrady relacyjne w znacznie większym zakresie (z możliwością odwołania posła i wyboru nowego) ${ }^{81}$. Jednak te rozwiąania ustawowe nie miały okazji zostać zastosowane w praktyce. Sejmiki lutowe $z 1792$ r. powinny realizować zadania zgromadzeń: deputackich, gospodarskich i elekcyjnych, choć zdaniem Adama Lityńskiego spełniały także funkcję sejmików relacyjnych ${ }^{82}$. W świetle opublikowanych akt kowieńskich pewne cechy takiego zgromadzenia miał sejmik gospodarski z 15-18 lutego 1792 r. Wprawdzie $\mathrm{w}$ uchwalonym wówczas laudum w sprawie sejmu, zawierającym m.in. zaprzysiężenie Konstytucji 3 maja, termin relacja nie pojawił się, jednak uchwała nie pozostawia watpliwości, że posłowie kowieńscy informowali szlachtę o przebiegu wydarzeń na sejmie ${ }^{83}$.

Przeprowadzona przez M. Jusupović analiza statystyczna akt wydawanych przez sejmiki kowieńskie (202 dokumenty) dostarcza interesujących danych. Najliczniejszą grupę uchwał stanowią kredensy dla: a) dla urzędników i osób pełniących funkcje powiatowe (45); b) dla deputatów trybunalskich (43); c) dla posłów na sejm (13). Liczne sa także (30) instrukcje, najczęściej poselskie ${ }^{84}$. Autorka przytoczyła pogląd, że zwłaszcza w czasach Augusta III kredensy dla posłów mogły zanikać (zachował się jeden), a ich rolę odgrywały instrukcje poselskie. Według A. Rachuby to one były uważane za ważniejsze niż inne uchwały ${ }^{85}$. Liczne kredensy poselskie $z$ czasów Stanisława Augusta świadcza zdaniem M. Jusupović, że w drugiej połowie XVIII w. nastapił powrót do zwyczaju ich wydawania $^{86}$. Zjawisko to znajduje potwierdzenie w praktyce sejmikowej powiatów lidzkiego i wiłkomierskiego z czasów Rady Nieustającej.

81 Vol. leg., t. IX, s. 233, 238 (ustawa Sejmiki); A. Lityńs ki, Sejmiki ziemskie 1764-1793. Dzieje reformy, Katowice 1988, s. 124-125, 164.

${ }^{82}$ W. Szczygielski, op. cit., s. 21; A. Lityński, Sejmiki województwa płockiego..., s. 82. Por. też R. Butterwick, op. cit., s. 746-758.

${ }^{83}$ Akta sejmiku kowieńskiego..., s. 497-498. Por. W. Szczygielski, op. cit., s. 312-313.

${ }^{84}$ Akta sejmiku kowieńskiego..., s. 20.

85 A. Rachuba, Wielkie Księstwo Litewskie..., s. 131.

${ }^{86}$ Akta sejmiku kowieńskiego..., s. 20. 
W księgach grodzkich $z$ lat 1776-1786 znajdują się kredensy dla posłów na każdy $z$ sześciu sejmów, które zebrały się w tym okresie ${ }^{87}$.

Mniej jednolicie wyglądała praktyka różnych powiatów, jeśli chodzi o urzędników wybieranych przez sejmiki elekcyjne (w 1764 r. sejm usankcjonował zasadę, że szlachta litewska wybierała urzędnika, a nie kandydata na urząd elekcyjny) ${ }^{88}$. W Kownie sejmik uchwalał kredens dla wybranego urzędnika (na sejmiku z 7 lutego 1765 uchwalono aż osiem takich dokumentów $\left.{ }^{89}\right)$. Podobnie w czasach Rady Nieustajacej wyglądała praktyka w powiecie lidzkim. Na sejmiku elekcyjnym w Lidzie obradujacym 11-12 lutego $1784 \mathrm{r}$. wybrano trzech urzędników (podkomorzego, marszałka powiatowego i sędziego ziemskiego). Każdy z elektów otrzymał osobny kredens (w źródle pojawia się też termin „instrument kredensjonalny”), który został aktykowany w księgach grodzkich ${ }^{90}$. Inaczej wyglądała formuła decyzji sejmiku elekcyjnego w Wiłkomierzu, który obradował trzy lata wcześniej. Zgromadzona 7 lutego 1781 r. szlachta wiłkomierska wybrała wówczas czterech urzędników (marszałka, chorążego, sędziego i pisarza ziemskich), co zostało ogłoszone w jednym dokumencie wpisanym do księgi grodzkiej pod nazwa „uniwersalnego electionis na sejmiku gromnicznym instrumentu" ${ }^{\prime 1}$.

87 Dla powiatu lidzkiego dokumenty te znajduja się w: NGAB, fond 1722, wopis 1 , sprawa $12,13,14$. Dla powiatu wiłkomierskiego można je znaleźć w: LVIA, fondas SA, sygn. 13932, 13933, 13934, 13935, 13937, 13939. Wiłkomierskie sejmiki poselskie szerzej omówione sa w artykułach: W. Filipczak, Sejmiki $w$ Wiłkomierzu $w$ czasach dominacji Antoniego Tyzenhauza (1777-1780), [w:] Parłamientaryzm u Wialikim Kniastwie Litouskim..., s. 230-258; oraz idem, Sejmiki wiłkomierskie...

88 A.B. Zakrzewski, Sejmiki Wielkiego Księstwa Litewskiego epoki..., s. 61; Urzędnicy Wielkiego Księstwa Litewskiego. Spisy, t. II (Województwo trockie XIVXVIII wiek), red. A. Rachuba, oprac. H. Lulewicz, A. Rachuba, P.P. Romaniuk, A. Haratym, współpraca A. Macuk, J. Aniszczanko, Warszawa 2009, s. 30-31; W. Fili p czak, Elekcje ziemskich urzędników sąowych w czasach Rady Nieustajacej, [w:] Wokół wolnych elekcji $w$ państwie polsko-litewskim XVI-XVIII wieku. O znaczeniu idei wyboru - między prawami a obowiazkami, red. M. Markiewicz, D. Rolnik, F. Wolański, Katowice 2016, s. 583.

89 Akta sejmiku kowieńskiego..., s. 178-186.

${ }^{90}$ Kredens na podkomorstwo lidzkie dla T. Narbutta, Lida 11 II 1784 (aktykacja 12 II), kredens na marszałkostwo lidzkie dla F.A. Alexandrowicza, Lida 11 II 1784 (aktykacja 13 II), kredens na sęstwo ziemskie lidzkie dla Antoniego Alexandrowicza, Lida 12 II 1784 (aktykacja 13 II), NGAB, fond 1722, wopis 1, sprawa 13, k. 631-632v, 636-639v.

${ }^{91}$ Instrument uniwersalny elekcji na sejmiku gromnicznym, Wiłkomierz 7 II 1781 (oblata 8 II), LVIA, fondas SA, sygn. 13934, k. 452-455v. 
Dość liczne w powiecie kowieńskim były manifesty przeciwko sejmikom (17), z czego aż pięć przypadało na czasy Rady Nieustającej ${ }^{92}$. Nie może to dziwić, biorąc pod uwagę, że kilka zgromadzeń $\mathrm{w}$ tym okresie zostało rozdwojonych. Dla porównania w powiecie wiłkomierskim spotkałem na przestrzeni 10 lat (1776-1786) dwa takie dokumenty związane $z$ rywalizacja $o$ mandaty poselskie: manifest (pod nazwa „procesu”) i remanifest $z$ lipca 1776 r. ${ }^{93}$

Lauda, podstawowy typ dokumentów sejmikowych w Koronie, przez przeszło 60 lat wystapiły w Kownie tylko 13 razy. Monika Jusupović postuluje zbadanie, czy nie jest to zjawisko specyficzne dla powiatu kowieńskiego lub dla XVIII w. ${ }^{94} \mathrm{Z}$ moich obserwacji wynika, że podobnie sytuacja wyglądała także w innych powiatach Wielkiego Księstwa Litewskiego. Na przestrzeni 10 lat (1776-1786) w lidzkich księgach grodzkich aktykowane były jedynie kredensy $\mathrm{i}$ instrukcje. W powiecie wiłkomierskim w tym samym czasie tylko raz efektem obrad było laudum, co nastapiło na wzmiankowanym już sejmiku gospodarskim $z$ lutego 1783 r. ${ }^{95} \mathrm{~W}$ czasach Rady Nieustającej termin laudum, uznany przez A.B. Zakrzewskiego za najpojemniejsze określenie uchwały sejmikowej ${ }^{96}$, był dość rzadko używany w wielu powiatach litewskich. W aktach kancelarii mniejszej litewskiej wśród dziewięciu dokumentów dotyczących sejmikowych wyborów na urzędy (w latach 1775-1781) jest osiem kredensów $^{97}$. Jest tylko jedno laudum, uchwalone na sejmiku powiatu orszańskiego w Chołopieniczach (w lutym 1781 r.), które jednak dotyczy całości obrad gromnicznych: deputackich, gospodarskich (rozpoczętych relacją $z$ sejmu) oraz elekcyjnych ${ }^{98}$. Szlach-

92 Akta sejmiku kowieńskiego..., s. 21, 293-301, 311-318, 405-411.

${ }^{93}$ Proces [manifest] sejmiku antekomicjalnego, Wiłkomierz 16 VII 1776 (wpisany do ksiag grodzkich tego samego dnia), remanifest urzędników powiatu wiłkomierskiego, Wiłkomierz 16 VII 1776 (oblata 17 VI), LVIA, fondas SA, sygn. 13932, k. $186-192$ i $208-210 v$.

94 Akta sejmiku kowieńskiego..., s. 21.

95 Laudum powiatu wiłkomierskiego dla J. Kuszelewskiego, Wiłkomierz 4 II 1783, LVIA, fondas SA, sygn. 13936, k. 36-37v.

${ }_{96}$ A.B. Zakrzewski, Sejmik trocki..., s. $114-115$.

${ }^{97}$ Kredensy na sęstwa ziemskie: rzeczyckie (Bobrujsk 7 II 1775), trockie (Troki 8 II 1775), żmudzkiego (Rosienie 7 II 1776), wileńskie (Wilno 7 II 1781), smoleńskie (Olita 7 II 1781 - dwa dokumenty), mozyrskie (Mozyr 7 II 1781), orszańskie (Chołopienicze 9 II 1781), Biblioteka Czartoryskich w Krakowie [dalej: BCz], rkps 861, s. 365-371, 373-379, 385-386, 429-435, 437-438, 441-442, 445-446, 457.

98 Laudum sejmików gromnicznych powiatu orszańskiego (Chołopienicze 9 II 1781); $\mathrm{BCz}$, rkps 861, s. 449-455 (wypis z ksiag ziemskich). 
ta orszańska uchwaliła wówczas zarówno laudum, jak i kredens dla wybranego urzędnika. Warto też odnotować, że w kancelaryjnym regestrze cztery $z$ wymienionych uchwał (żmudzka, egzulanckie smoleńskie i mozyrska), będące kredensami, jak wynika $z$ ich treści, zostały określone jako lauda ${ }^{99}$. Wydawanie kredensu na urząd elekcyjny nie było jednak powszechną regułą. Niejednorodność praktyki uwidacznia się wyraźniej w aktach kancelarii mniejszej litewskiej $z$ lat kolejnych (1782-1787). Wciąż liczne sa kredensy (np. powiat brasławski), ale na niektórych sejmikach dominuja lauda (m.in. powiat grodzieński ${ }^{100}$ ). W wielu powiatach szlachta stosowała obie formy dokumentów, np. sejmiki żmudzki czy wołkowyski ${ }^{101}$.

Do innych dokumentów powstałych w związku z obradami sejmików kowieńskich należą sufragia (7) i diariusze (3) ${ }^{102}$. Na czasy Rady Nieustającej przypada jeden diariusz (1779) i sześć wykazów oddanych głosów (w 1776 r. - dwa dokumenty; po jednym w latach: $1779,1780,1784,1785)^{103}$. Monika Jusupović zdefiniowała sufragia jako „głosy oddawane podczas elekcji urzędników lub wyboru deputatów"104. Formuła ta ma uzasadnienie w przepisach prawa obowiazującego na Litwie. W ustawie sejmu koronacyjnego 1764 r., która dotyczyła sejmików deputackich, elekcyjnych i gospodarskich, omówiono procedurę oddawania głosów i sporządzania sufragiów ${ }^{105}$. Ustawa, przywracająca w wyborach przyjętą w 1613 r. w Wielkim Księstwie zasadę większości głosów, nie dotyczyła jednak sejmików przedsejmowych ${ }^{106}$. Przykład sejmiku wiłkomierskiego $z$ lipca 1776 r. pokazuje, że sufragia spisywano także przy wyborach posłów ${ }^{107}$.

99 Regestr laudów sejmikowych na urzędy oraz sancitów na starostwa i dzierżawy, BCz, rkps 861, s. 359-361.

100 Cztery kredensy sejmików w Brasławiu (8 II 1785), lauda sejmików w Grodnie (11 II 1784, 8 II 1786), BCz, rkps 879, s. 239-257 (uchwały brasławskie), 199-203, 207-211, 407-411 (lauda grodzieńskie).

101 Akta kancelarii mniejszej Wielkiego Księstwa Litewskiego 1782-1792, BCz, rkps 879, s. 132-164, 303, 305-315 (Rosienie), 225-226, 343-355 (Wołkowysk).

102 Akta sejmiku kowieńskiego..., s. 21.

103 Ibidem, s. 256-264, 287-293, 318, 365-373, 399-405.

104 Ibidem, s. 21.

105 Vol. leg., t. VII, s. 171 (ustawa: Sejmiki elekcyjne, deputackie i ziemskie).

106 J. Michals ki, Sejm w czasach panowania Stanisława Augusta, [w:] Historia sejmu polskiego, red. J. Michalski, Warszawa 1984, s. 357; A.B. Zakrzew ski, Sejmik trocki..., s. 73, 83-84.

107 Akt wotów sejmiku antekomicjalnego, Wiłkomierz 15 VII 1776, i sufragia na Benedykta Morykoniego, Wiłkomierz 15 VII 1776 (dokumenty oblatowano 17 VII), LVIA, fondas SA, sygn. 13932, k. 211-216. 
Specyficznym rysem życia politycznego powiatu kowieńskiego był konflikt sejmikowy, który toczył się w czasach Rady Nieustającej. W wielu powiatach litewskich doszło do ostrej rywalizacji w latach 1779-1780, co miało związek z kryzysem pozycji podskarbiego nadwornego Antoniego Tyzenhauza jako lidera litewskich regalistów ${ }^{108}$. Jednak po upadku podskarbiego nadwornego $\mathrm{w}$ połowie $1780 \mathrm{r}$. w następnych latach sytuacja polityczna się ustabilizowała, a nowym liderem stronnictwa dworskiego w Wielkim Księstwie był podkanclerzy litewski Joachim Chreptowicz ${ }^{109}$. Inaczej było $\mathrm{w}$ powiecie kowieńskim, gdzie konflikt nasilił się w wyniku rozdwojenia obrad sejmiku elekcyjnego w lutym $1784 \mathrm{r}$. Stronnictwo Zabiełłów i Kossakowskich sprzeciwiało się wyborowi na podkomorzego kowieńskiego Tomasza Wawrzeckiego, którego popierał podkanclerzy J. Chreptowicz ${ }^{110}$. Odbiciem wspomnianego konfliktu sa trzy dokumenty opublikowane w Aktach sejmiku kowieńskiego (w aneksie 1). Dwa $z$ nich sa związane $z$ rugami trybunalskimi w 1785 r. Pierwszym jest drukowany „wykład sprawy przychodzącej pod rozpoznanie Trybunału przy rugach o sejmiki deputackie powiatu kowieńskiego 1785 roku"111, który przedstawia argumenty za uznaniem legalności deputatów promowanych przez partię Zabiełłów i Kossakowskich. Drugi dokument, związany $z$ rugami deputackimi w 1785 r., to decyzja w tej sprawie podjęta przez Trybunał Główny Wielkiego Księstwa Litewskiego na posiedzeniu 4 maja 1785 r. ${ }^{112}$ Ostatnim dokumentem zamieszczonym w aneksie 1 jest decyzja Trybunału Litewskiego $z 4$ maja 1786 r. w sprawie rozdwojonego sejmiku kowieńskiego $z$ lutego tegoż roku. Także tym razem Sąd Główny Wielkiego Księstwa Litewskie-

108 S. Kościałkowski, op. cit., t. II, s. 363-370, 408-411; W. Filipczak, Anna z Pociejów Tyszkiewiczowa, wojewodzina smoleńska. Rola polityczna w czasach Rady Nieustajacej, [w:] Kobiety i władza w czasach dawnych, red. B. Czwojdrak, A.A. Kluczek, Katowice 2015, s. 416-421.

109 A. Kalenkiewiczówna, op. cit., s. 128-154; J. Michalski, Sejmiki poselskie 1788 roku, cz. 1-2, "Przegląd Historyczny” 1960, t. LI, z. 1-2, s. 53, 354; W. Filipczak, Ekonomie litewskie..., s. 238-240.

110 J. Chreptowicz do króla, Szczorsy 9 i 14 VII 1784, BCz, rkps 724, s. 251-256; M. Ju su p ović, Prowincjonalna elita..., s. 304-306.

111 Akta sejmiku kowieńskiego..., s. 521-530. Dokument ten został przez wydawcę nazwany niezbyt trafnie „Protestem przeciw deputatom kowieńskim”.

112 Trybunał Litewski uznał legalność wyboru na deputatów T. Wawrzeckiego i Piotra Zawiszy, sędziego ziemskiego kowieńskiego. Por. ibidem, s. 530-532; Deputaci Trybunału Głównego Wielkiego Księstwa Litewskiego 1697-1794. Spisy, red. A. Rachuba, oprac. A. Rachuba, P.P. Romaniuk, współpraca A. Macuk, J. Aniszczenko, Warszawa 2004, s. 367-368; A. Stankevič, op. cit., s. 104. 
go uznał legalność obradującego na zamku zgromadzenia, któremu prezydował podkomorzy T. Wawrzecki ${ }^{113}$.

Miejsce obrad sejmikowych było ważnym argumentem, który wpływał na decyzje trybunalskie uznające nielegalność zgromadzeń kierowanych przez partię Zabiełłów, a obradujących w kościele bernardyńskim (w 1786 r. na cmentarzu przykościelnym) ${ }^{114}$. Wydane w aneksie 1 do Akt sejmiku kowieńskiego źródła nie sa jednak jedynymi dokumentami, które dotyczyły powyższego problemu. Na sesji Rady Nieustającej z 15 listopada 1785 r. przyjęta została rezolucja będąca odpowiedzią na memoriał marszałka kowieńskiego Ignacego Zabiełly, w którym odnosił się do wątpliwości prawnych w sprawie miejsca sejmikowania ${ }^{115}$. Rezolucja magistratury, za wydaniem której stał biskup Józef Kossakowski, wyznaczała na miejsce odbywania sejmików kościół bernardyński ${ }^{116}$. Stało się to przyczyna niezadowolenia partii T. Wawrzeckiego i Prozorów. Jej liderzy pisali do króla, że decyzja Rady Nieustającej naruszyła „prawo statutowe” (III Statut Litewski) i trzy dekrety trybunalskie, które nakazywały obrady na zamku ${ }^{117}$. Listopadowa rezolucja Rady nie zakończyła sporu o miejsce sejmików. Konsekwencją było rozdwojenie obrad gromnicznych w lutym 1786 r. i wspomniana decyzja Trybunału Litewskiego.

Niezadowoleni z przyjętego przez sąd rozstrzygnięcia, przywódcy ugrupowania Zabiełłów i Kossakowskich podjęli starania o zmianę sytuacji prawnej. Efektem tych działań był zgłoszony na sejmie w 1786 r., przez posłów kowieńskich Szymona Zabiełłę i Józefa Medekszę, projekt w sprawie miejsca obrad sejmikowych. Zgodnie z nim rezolucja Rady z 15 listopada 1785 r. miała obowiązywać na całej Litwie ${ }^{118}$. Szymon Zabiełło wystapił w tej sprawie na sesji

113 Akta sejmiku kowieńskiego..., s. 532-534; Deputaci Trybunału..., s. 371372; A. Stankevič, op. cit., s. 105.

${ }_{114}$ M. Jusupović, Problem legalnego..., s. 845-846; A. Stankevič, op. cit., s. $104-105$.

115 Protokół potoczny Rady Nieustającej z 15 XI 1785, AGAD, ML, dz. VII, sygn. $56, \mathrm{k} .28 \mathrm{v}-29$.

116 M. Jus u pović, Prowincjonalna elita..., s. 315.

117 T. Wawrzecki do króla, Wilno 22 XI 1785; BCz, rkps 698, s. 1413; Antoni Prozor do króla z 16 XII 1785, BCz, rkps 698, s. 371-372. Por. też M. Ju s u pović, Problem legalnego..., s. 847-848.

118 Projekt o miejscu sejmików, AGAD, ZP, sygn. 59, k. 103-103v (projekt drukowany w: AGAD, ZP, sygn. 105, k. 48); W. Filipczak, Rugi poselskie i losy "rozdwojonych” sejmików przedsejmowych 1778-1786, „Czasopismo Prawno-Historyczne" 1997, t. XLIX, z. 1-2, s. 83. Dodatkową okazję do zgłoszenia projektu 
28 października 1786 r. Poseł kowieński domagał się natychmiastowego przeczytania projektu. Groził, że jeśli to nie nastąpi, nie zgodzi się na przystapienie do dalszych czynności sejmowych ${ }^{119}$. W mowie poselskiej S. Zabiełło bronił rezolucji Rady z 15 listopada i powołał się na instrukcję swojego sejmiku ${ }^{120}$. Jednak $z$ jej tekstu ogłoszonego w Aktach sejmiku kowieńskiego wynika, że nie miało to podstaw $^{121}$. Natychmiastowemu odczytaniu projektu sprzeciwili się posłowie grodzieńscy (byli nimi: choraży nadworny litewski Antoni Wołłowicz i stolnik starodubowski Konstanty Jelski ${ }^{122}$ ). Przedstawiciele powiatu kowieńskiego, wsparci przez innych reprezentantów Litwy, doprowadzili w końcu do przeczytania projektu. Izba poselska uznała jednak, że sprawą należy się zająć w późniejszym czasie $^{123}$. Inicjatywa ta nie doczekała się realizacji.

Zdecydowana większość kowieńskich akt sejmikowych zachowała się w księgach sądowych: grodzkich i ziemskich ${ }^{124}$. W odniesieniu do Litwy $\mathrm{w}$ interesujacych mnie czasach jest to sytuacja typowa. Trochę oryginalnych uchwał sejmikowych, dotyczacych przede wszystkim elekcji na urzędy, można znaleźć w aktach kancelarii mniejszej litewskiej ${ }^{125}$. Zazwyczaj jednak dostępne sa jedynie wpisy dokumentów do ksiąg sądowych. Dobra ilustrację tej sytuacji daja wydane przez litewskich historyków instrukcje poselskie na Sejm Wielki ${ }^{126}$. W odniesieniu do omawianego okresu czasami dysponujemy także wypisami $z$ ksiagg grodzkich ${ }^{127}$. Na szczęście dla

stworzyły spory wokół wpływu miejsca obrad na legalność sejmiku, które toczyły się w czasie rugów poselskich. Por. też A. D a nil czyk, W kręgu afery Dogrumowej. Sejm 1786 roku, Warszawa 2010, s. 134-138.

119 Diariusz sejmu 1786 r., AGAD, Archiwum Królestwa Polskiego [dalej: AKP], sygn. 356, s. 253-256 (według dawnej paginacji: AKP, sygn. 356, cz. 2, k. 7-8).

120 Głos [...] Szymona Zabiełty [...] r. $1786 w$ izbie poselskiey na wolnym seymie miany, [w:] Zbior mów, głosów, przymówien, manifestów, remanifestów, etc., mianych na seymie roku 1786, t. II, Warszawa 1787, s. 681-684.

${ }^{121}$ Akta sejmiku kowieńskiego..., s. 431-433.

122 A. Danilczyk, op. cit., s. 108.

123 Diariusz sejmu 1786 r., AGAD, AKP, sygn. 356, s. 255-256 (według dawnej paginacji: AKP, sygn. 356, cz. 2, k. 8).

${ }^{124}$ Akta sejmiku kowieńskiego..., s. 26-27.

125 Akta kancelarii mniejszej Wielkiego Księstwa Litewskiego 1771-1781, BCz, rkps 861, s. 385-386, 437-438, 441-442, 445-446, 457. Kontynuacja tych akt (z lat 1782-1792) znajduje się w: $\mathrm{BCz}$, rkps 879. Por. Akta sejmiku kowieńskiego..., s. 347-348.

126 Lietuvos Dzidžiosios Kunigaikštystès..., s. 21-22.

127 Sporo instrukcji poselskich $z$ listopada 1790 r. w formie wypisów $z$ ksiag grodzkich (lub kopii) znajduje się w: Lietuvos mokslu akademijos Vrublevskiu bi- 
historyków księgi sądowe wielu powiatów litewskich zachowały się $\mathrm{w}$ dość szerokim zakresie, przynajmniej w stosunku do omawianego okresu.

Jednak już w drugiej połowie XVIII w. pojawiały się trudności $\mathrm{w}$ utrzymaniu akt sądowych $\mathrm{w}$ należytym stanie. Wynikały one np. z niemożności zapewnienia właściwych warunków przechowywania ksiag, co było konsekwencja pozbawienia sejmików własnych źródeł dochodów w latach 1766-1768. Przykładem takiej sytuacji może być powiat kowieński, gdzie nie została zrealizowana ustawa sejmu koronacyjnego z 1764 r., która przewidywała budowę murowanych archiwów służących do przechowywania akt sądowych ${ }^{128}$. Wspominając te problemy, M. Jusupović w sposób błędny zinterpretowała zapis kowieńskiej instrukcji poselskiej na sejm w $1766 \mathrm{r}$. We wstępie do Akt sejmiku kowieńskiego czytamy: „W roku 1766 $\mathrm{w}$ instrukcji zamieszczono propozycję przeznaczenia dochodów $z$ ekonomii kowieńskiej na budowę archiwum, ale zdaje się, że planu tego nie wykonano" 129 . Realizacja tak sformułowanego zadania nie była możliwa, gdyż nie istniała ekonomia kowieńska. $Z$ badań S. Kościałkowskiego wynika, że w początkowym okresie panowania Stanisława Augusta funkcjonowało na Litwie pięć ekonomii: grodzieńska, olicka, szawelska, brzesko-kobryńska i mohylewska (ta ostatnia znalazła się poza granicami Rzeczypospolitej po pierwszym rozbiorze) ${ }^{130}$. Jedyna wattpliwość w tym czasie dotyczyła problemu, czy ekonomia olicka była jednostka samodzielna, czy stanowiła gubernię wchodząca w skład ekonomii grodzieńskiej ${ }^{131}$. O istnieniu „ekonomii kowieńskiej” nie mogło być więc mowy. Zapewne miała tego świadomość szlachta kowieńska, pisząc instrukcję na

blioteka, fondas 17, sygn. 9. Jako przykład mogą służyć instrukcje poselskie: grodzieńska (k. 71-89) i wileńska (k. 160-169v). Z polskich archiwaliów można wymienić warszawskie Archiwum Radziwiłłów [dalej: AR], m.in. instrukcja poselska, Wilno 23 VIII 1780 (sejmiki zwołano na 21 VIII), AGAD, AR, dział II, sygn. 3136, s. 1-7; laudum sejmiku gromnicznego, Mińsk 3[-4] II 1783, AGAD, AR, dział II, sygn. 3157, s. 1-7. Na sesji 4 II 1783 r. na starostę grodowego mińskiego wybrany został Hieronim Radziwiłł. Por. też D. Rolnik, Województwo mińskie i Jeleńscy $w \dot{z} y c i u$ publicznym Rzeczypospolitej $w$ latach 1764-1795 w świetle ich korespondencji, Katowice 2018, s. 206.

128 Vol. leg., t. VII, s. 179 (ustawa: O księgach i aktach). Na temat losów budowy archiwum w Trokach por. A.B. Zakrzews ki, Sejmik trocki..., s. 200-202.

129 Akta sejmiku kowieńskiego..., s. 27.

130 S. Kościałkowski, op. cit., t. I, s. 607-621.

131 Ibidem, t. I, s. 523-525. 
sejm w 1766 r. Nieporozumienie wyniknęło z błędnego zrozumienia odpowiedniego jej fragmentu. W punkcie nr 14 instrukcji czytamy bowiem, że intraty starostwa kowieńskiego sa zbyt niskie, aby zapewnić utrzymanie urzędu starościńskiego, a tym bardziej nie pozwalaja na budowę archiwum i utrzymanie w porządku ksiąg grodzkich, co przewidywała ustawa sejmu koronacyjnego. Sejmik postulował więc przywrócenie ekonomii kowieńskiej (powołano się $\mathrm{w}$ tej sprawie na postanowienia przywileju Zygmunta III Wazy). Wariant alternatywny brzmiał następujaco: „albo dalszemi łaskami [...] aby tenże j.w.j.p. starosta kowieński był opatrzony, instabunt i.p. posłowie"132. Oczywiście żadna $z$ tych możliwości nie doczekała się realizacji.

Praktyka parlamentarna stwarzajaca badaczom litewskich akt sejmikowych wiele problemów był zwyczaj wystawiania odrębnych kredensów dla każdej $z$ osób wybranych na funkcję (poselską lub deputacka). Rozwiazania w tym zakresie mogły się różnić w zależności od powiatu. W Wiłkomierzu (w latach 1776-1786) do oblaty podawano zazwyczaj jeden akt kredensu dla obu elektów. Zdarzały się jednak od tej zasady odstępstwa, zwłaszcza od 1784 r. W lutym 1784 r. wystawiono osobne kredensy dla każdego $z$ deputatów. Przy wpisie do księgi grodzkiej wyraźnie zaznaczono, komu miał służyć dany dokument (choć w obu tekstach deputaci wymienieni sa w tej samej kolejności) ${ }^{133}$. Podobna sytuacja zaszła na sejmiku deputackim w roku następnym, kiedy we wpisie do księgi grodzkiej dodatkowo stwierdzono, której kadencji ma dotyczyć dany kredens ${ }^{134}$. W lutym 1786 r. w grodzie wiłkomierskim oblatowano akt kredensu dla jednego tylko deputata (oczywiście obaj wymienieni byli w jego treści) ${ }^{135}$. Inaczej wyglądała praktyka w powiecie lidzkim, gdzie zazwyczaj wystawiano osobne kredensy dla obu wybranych osób (dotyczyło to deputatów i posłów). Jednak i tu pojawiały się wyjątki od reguły. Czasami w księgach grodzkich z lat 1776-1786

132 Akta sejmiku kowieńskiego..., s. 208.

133 Kredens dla Chryzostoma Nowomieyskiego, Wiłkomierz 9 II 1784, i kredens dla Justyna Parafianowicza, Wiłkomierz 9 II 1784, LVIA, fondas SA, sygn. 13937, k. 22-23v.

${ }^{134}$ Kredens dla Józefa Wiszniewskiego (kadencja wileńska), Wiłkomierz 8 II 1785, i kredens dla Antoniego Lachnickiego (kadencja grodzieńska), Wiłkomierz 8 II 1785, LVIA, fondas SA, sygn. 13938, k. 25-30v.

135 Kredens dla Michała Kuszelewskiego, Wiłkomierz 6 II 1786, LVIA, fondas SA, sygn. 13939, k. 89-89v. 
aktykowano tylko jeden akt kredensu. Tak było po sejmiku poselskim w 1776 r. ${ }^{136}$, a także po sejmikach deputackich w 1779, 1782 i 1785 r., kiedy akty kredensu były wystawione dla obu elektów ${ }^{137}$. Po wyborze sędziego trybunalskiego w 1777 r. do ksiagg grodzkich wpisano kredens wystawiony dla jednego deputata ${ }^{138}$.

Niestety Akta sejmiku kowieńskiego nie pozwalają na jednoznaczne ustalenie praktyki wystawiania kredensów w powiecie kowieńskim. Monika Jusupović nie wyjaśniła bowiem, jak postępowano w czasie prac nad edycja w sytuacjach (zakładajac, że miały one miejsce), gdy każdy z dokumentów miał służyć innej osobie. Możemy się tego jedynie domyślać na podstawie sformułowania dotyczacego podstawy wydania dokumentów: „W nielicznych wypadkach, kiedy dysponujemy dwiema kopiami tak samo bliskimi oryginałowi i nie różniącymi się tekstem, za podstawę zazwyczaj służyła ta, która w księdze sądowej występuje jako pierwsza"139. Należy założyć, że taka sytuacja powstała, jeśli w aktach powiatu aktykowano dwa kredensy, co - jak wynika $z$ cytowanego sformułowania - nie było częste. Kiedy istniały liczne różnice w odniesieniu do podpisów pod dokumentami, w wydawnictwie osobno opublikowane sa podpisy spod obu „kopii” ${ }^{140}$.

Spróbuję dokonać wyrywkowej analizy kowieńskiej praktyki wystawiania kredensów na funkcje publiczne. Za przykład posłużą dane $z$ lat 1781-1783, $z$ okresu względnego spokoju, kiedy sejmiki kowieńskie nie były rozdwajane. W Aktach sejmiku kowieńskiego tylko w odniesieniu do sejmiku deputackiego z 5 lutego $1781 \mathrm{r}$. wymieniony jest jeden rękopis kredensu ${ }^{141}$. Dla zgromadzenia deputackiego $z$ 4-5 lutego 1782 r. sa wprawdzie dwa, ale tylko jeden pochodzi $z$ akt ziemskich (drugi to oryginał $z$ Biblioteki Czartoryskich) ${ }^{142}$. Dwa rękopisy pojawiły się w metryczkach dokumentów następujących sejmików: przedsejmowego z 19 sierpnia $1782 \mathrm{r}$.

136 Kredens dla posłów na sejm, Lida 16 VII 1776, NGAB, fond 1722, wopis 1 , sprawa 12, k. 65-67v.

137 Kredens dla deputatów, Lida 8 II 1779 i 4 II 1782 (aktykacja 16 II 1782), NGAB, fond 1722, wopis 1 , sprawa $12, \mathrm{k}$. 275-278v, 983-984v; kredens dla deputatów, Lida 7 II 1785, NGAB, fond 1722, wopis 1, sprawa 13, k. 988-989v.

138 Kredens na deputata dla Joachima Rossudowskiego, Lida 3 II 1777, NGAB, fond 1722 , wopis 1 , sprawa $12, \mathrm{k} .96-97 \mathrm{v}$.

139 Akta sejmiku kowieńskiego..., s. 28.

140 Ibidem, s. 28, 281-285, 305-311, 413-424.

141 Ibidem, s. 343-345.

142 Ibidem, s. 345-347. 
oraz deputackiego z 3 lutego 1783 r. ${ }^{143} \mathrm{~W}$ stosunku do każdego $z$ wymienionych sejmików oba rękopisy pochodzą $z$ tej samej księgi sądowej i umieszczone są bezpośrednio po sobie. Można więc założyć, że chodzi o odrębne kredensy wystawione dla deputatów lub posłów (nie ma jednak pewności, czy dla każdego $z$ nich osobno). Utwierdza $\mathrm{w}$ tym przekonaniu brak znaczących różnic pomiędzy rękopisami dotyczącymi tego samego zgromadzenia (drobne różnice zostały przedstawione w przypisach), choć bardzo wycinkowa, powyższa analiza sugeruje, że w Kownie stosowane były obie praktyki: oblatowania jednego kredensu dla dwóch osób albo wpisywania osobnych kredensów służących elektom (mowa tu o wyborach dokonanych zgodnie). W powiecie kowieńskim w czasach Rady Nieustającej aktykacja dwóch kredensów nie była wcale rzadka. Nie dziwi mnie traktowanie w Aktach sejmiku kowieńskiego obu dokumentów jako jednego tekstu. Praktycznie nie było między nimi różnic albo dotyczyły tylko drobiazgów (wyjątkiem mogły być podpisy). Ze względów praktycznych zrezygnowano $z$ powtarzania $\mathrm{w}$ druku tych samych sformułowań, ale $z$ formalnego punktu widzenia mogły to być dwa odrębne, choć niemal identyczne, dokumenty ${ }^{144}$.

Specyficznym rysem sejmików na Litwie był zwyczaj zamieszczania podpisów uczestników zgromadzenia pod uchwałami. Dotyczyło to nie tylko manifestów, lecz także kredensów, laudów czy instruk$\mathrm{cji}^{145}$. Podpisy pod aktami sejmikowymi dają historykom duże możliwości badawcze. Świadczą o tym wykazy szlachty poszczególnych powiatów Wielkiego Księstwa ( $z$ terenów obecnej Białorusi) wydane przez Jewgienija Aniszczenkę ${ }^{146}$. Przy badaniu podpisów pod aktami powstaje jednak szereg problemów, które związane są np. $z$ identyfikacją osób czy weryfikacją autentyczności podpisów. Dotyczy to zwłaszcza zgromadzeń rozdwojonych, gdzie liczba podpisów była ogromna. Przykładem są sejmiki kowieńskie $z$ lat 1779-1780 i 1784-1786, kiedy składano ich setki, a w 1784 r. na obradach deputackich prawie 1200 (stronnicy Zabiełłów) ${ }^{147}$. Jeszcze więcej

143 Ibidem, s. 351-352, 356-358.

144 Wydaje się, że w metryczce dokumentu należy umieszczać informację, komu dany kredens („rękopis” według nomenklatury przyjętej w Aktach sejmiku kowieńskiego) miał służyć, jeśli oczywiście taka wiadomość znajduje się w księgach sądowych.

145 Por. A. Rachuba, op. cit., s. 97.

146 Por. E. Aniszczenko, Szlachta Lidskogo powieta. Spisok. XVIII st., Minsk 2013.

${ }^{147} \mathrm{~W} 1780$ r. na sejmiku poselskim kontrolowanym przez Zabiełłów było ponad 900 podpisów: M. Ju s u pović, Uczestnicy sejmików kowieńskich w czasach 
podpisów pojawiało się w aktach rozdwojonego sejmiku elekcyjnego w 1791 r. (regaliści zdobyli ich przeszło 2000, zwolennicy Zabiełłów ponad 1000) ${ }^{148}$. W Wiłkomierzu setki podpisów znajduja się pod sufragiami na rozdwojonym sejmiku poselskim z 15-16 lipca 1776 r. Pierwszego posła (Tadeusza Kościałkowskiego) wybrano jednomyślnie. Do rozłamu doszło przy wyborze drugiego reprezentanta. Regaliści poparli szambelana Benedykta Morykoniego, a opozycja wybrała starostę rekancyskiego Kazimierza Zyberka ${ }^{149}$. Liczby podpisów były znacznie mniejsze, przekraczały jednak 300 osób, choć znaczną część stanowiły „krzyżyki” osób niepiśmiennych $^{150}$. Także w Koronie stosowano podpisywanie uchwał sejmiku przez ogół uczestników (rzeczywistych lub rzekomych) w sytuacji konfliktu w czasie obrad ${ }^{151}$. Jednak tutaj rzadziej spotykamy, przynajmniej w czasach Rady Nieustajacej, dokumenty $z$ podpisami składanymi w czasie sejmikowego głosowania, odpowiedniki litewskich sufragiów ${ }^{152}$.

Różnice między Korona a Litwą istniały w odniesieniu do zgromadzeń, na których nie doszło do poważniejszych konfliktów. W Koronie uchwały podpisywali zazwyczaj marszałek i asesorowie (w wypadku instrukcji mógł być to tylko marszałek). Na Litwie liczba podpisów, $z$ uwzględnieniem wielu zastrzeżeń, daje przybliżone wyobrażenie o liczebności zgromadzenia ${ }^{153}$. W wypadku sejmików

Augusta III $i$ Stanisława Augusta Poniatowskiego - teoria i praktyka, „Rocznik Lituanistyczny" 2016, t. II, s. 130-131. Por. też Akta sejmiku kowieńskiego..., s. 287-291, 294-297, 305-311, 313-315, 321-333, 360-373, 375-378, 384-387, 394-405, 413-431.

148 M. Ju su pović, Uczestnicy sejmików..., s. 131; Akta sejmiku kowieńskiego..., s. 458-488.

${ }^{149}$ Kredensy na poselstwo dla K. Zyberka i T. Kościałkowskiego oraz dla T. Kościałkowskiego i B. Morykoniego, Wiłkomierz 16 VII 1776, LVIA, fondas SA, sygn. 13932, k. 195-201v, 223-224v.

150 Manifest zwolenników K. Zyberka, Wiłkomierz 16 VII 1776, akt wotów sejmiku antekomicjalnego pttu wiłkomierskiego i sufragia na B. Morykoniego, Wiłkomierz 15 VII 1776 (oblata 17 VII), LVIA, fondas SA, sygn. 13932, k. 186-192, 211-216; W. Filipczak, Sejmiki w Wiłkomierzu...

151 A. Lityń ski, Sejmiki województwa płockiego..., s. 89 (przyp. 52); W. Bednaruk. op. cit., s. 102-103; W. Filipczak, Sejm 1778..., s. 72-73.

152 Przykładem takiego dokumentu, choć inaczej skonstruowanego niż litewskie sufragia, są głosy na kandydatów na deputatów województwa płockiego, Raciąż 15 VII 1780 (oblata 17 VII), AGAD, Płockie grodzkie oblaty, sygn. 22, k. 311314v; W. Filipczak, Sejmiki województwa płockiego..., s. 53.

${ }^{153}$ M. J u s u pović, Uczestnicy sejmików..., s. 130-132. Por. też A. Ra ch u ba, op. cit., s. 97. 
„spokojnych”, jak stwierdziła M. Jusupović, akta kowieńskie podpisywało zwykle od kilkunastu do niespełna 50 osób. Czasami były to jednak liczby znacznie większe: około 450 (instrukcja poselska w 1788 r.), a nawet ponad 850 (kredens dla posłów w 1786 r.) $)^{154}$. Dla porównania przytoczę dane dotyczace liczby podpisów pod instrukcjami poselskimi powiatu słonimskiego w czasach Augusta III (dotyczą dziewięciu instrukcji $z$ lat 1738-1762), które przedstawił A. Macuk. Liczba podpisów wahała się od 29 (1752 r.) do 107 (1754 r.). Pozostałe instrukcje sygnowało od 53 do 98 osób ${ }^{155}$. W latach 1781-1784 w Wiłkomierzu dokumenty sejmikowe podpisywało od 21 do 45 uczestników obrad ${ }^{156}$. Aby uzyskać porównywalne dane, przeprowadziłem analogiczne obliczenia dla zgromadzeń kowieńskich $z$ lat 1781-1783. Najwięcej podpisów (50) było pod kredensem deputackim z 5 lutego 1781 r. ${ }^{157}$ Najmniejszą ich liczbę (18) widzimy pod kredensem dla posłów podpisanym 19 sierpnia 1782 r. ${ }^{158}$ Instrukcję poselska przyjęta przez ten sam sejmik sygnowały tylko trzy osoby. Podpisy złożyli jednak nie wszyscy uczestnicy sejmiku, lecz marszałek powiatowy i dwóch delegowanych do instrukcji ${ }^{159}$. Taka sytuacja stanowiła rozwiazanie nietypowe na Litwie. Nie spotkałem się $z$ nim na sejmikach lidzkich i wiłkomierskich. Tylko trochę podobna sytuacja wystąpiła w Wilnie, przy układaniu instrukcji na sejm w 1780 r. Zalecenia dla posłów zostały podpisane 23 sierpnia (dwa dni po terminie, na który sejmik zwołano), a akt sygnowało siedem osób. Jednak tylko ostatnia $z$ nich podpisała się jako delegat do instrukcji ${ }^{160}$. Wytłumaczeniem rozwiazania zastosowanego w Kownie może być to, że pod instrukcją widnieje data 24 sierpnia 1782 r., zatem aż o pięć dni późniejsza niż pod kredensem ${ }^{161}$. Tworzenie instrukcji na burzliwy sejm „sołtykowski” okazało się bardzo czasochłonne i pozostawiono je najbardziej wytrwałym uczestnikom lokalnego życia politycznego.

154 M. Jus u pović, Uczestnicy sejmików..., s. 131.

155 A. Macuk, Pasolskija sojmiki Słonimskaha pawieta u panawannie Auhusta III, [w:] Da swajoj historyi: Siaredniawieczcza i Ranni Nowy czas: zbornik nawukowych artykułau, pryswieczanych pamiaci Pauła Łojki, red. W.A. Waronin, Minsk 2013, s. 105, 108-110, 113-115.

156 W. Filipczak, Sejmiki wiłkomierskie...

157 Akta sejmiku kowieńskiego..., s. 344-345.

158 Ibidem, s. 351-352.

159 Ibidem, s. 356.

160 Instrukcja poselska, Wilno 23 VIII 1780, AGAD, AR, dział II, sygn. 3136, s. 6-7.

161 Ibidem, s. 352, 356. 
Można się zastanawiać, nad czym tak długo dyskutowali autorzy instrukcji. Należy w tym kontekście przypomnieć negatywną ocenę wpływów J. Chreptowicza jako lidera litewskich regalistów na sejmie 1782 r, której dokonał w swoich pamiętnikach biskup Józef Kossakowski, jeden $z$ przywódców fakcji Zabiełłów ${ }^{162}$. Być może spory wokół kształtu kowieńskiej instrukcji poselskiej w 1782 r. były zapowiedzia otwartego konfliktu, jaki ujawnił się w tym powiecie w lutym $1784 \mathrm{r}$.

Omówione aspekty działalności sejmików kowieńskich, lidzkich czy wiłkomierskich stanowia przykłady szeregu cech charakterystycznych dla funkcjonowania litewskich instytucji parlamentarnych. Pokazują one, że pewne schematy badawcze stosowane przez historyków samorządu szlacheckiego w Koronie wymagają czasem poważnej modyfikacji w odniesieniu do sejmików litewskich. Choć, jak się wydaje, różnice dzielące obyczaje parlamentarne w obu częściach Rzeczypospolitej stopniowo się zmniejszały, to jednak w drugiej połowie XVIII w. były nadal znaczace. Zacieranie się odmienności życia sejmikowego na Litwie i w Koronie wynikało nie tylko $z$ recepcji wzorów polskich w Wielkim Księstwie. W czasach stanisławowskich dostrzec można proces odwrotny. W Koronie system sejmikowy zaczęto wzorować na bardziej uporządkowanych rozwiąaniach litewskich ${ }^{163}$.

\section{Bibliografia}

\section{Ź́nódeA ARCHIWALNE}

Archiwum Główne Akt Dawnych w Warszawie [AGAD]

Archiwum Królestwa Polskiego [AKP], sygn. 356.

Archiwum Radziwiłłów [AR], dział II, sygn. 3136, 3157.

tzw. Metryka Litewska [ML], dział VII, sygn. 52, 56.

Płockie grodzkie oblaty, sygn. 22.

Zbiór Popielów [ZP], sygn. 59, 111.

162 Pamiętniki Józefa Kossakowskiego biskupa inflanckiego 1738-1788, wyd. A. Darowski, Warszawa 1891, s. 139; W. Fili pczak, Ekonomie litewskie..., s. 269.

163 A.B. Zakrzews ki, Wielkie Księstwo Litewskie (XVI-XVIII w.). Prawo- ustrój - społeczeństwo, Warszawa 2013, s. 54-56. 
Archiwum Państwowe w Gdańsku sygn. $300,29 / 231$.

Archiwum Państwowe w Toruniu Katalog II, dział VII, sygn. 60.

Biblioteka Czartoryskich w Krakowie [BCz] rkps $698,724,861,879$.

Lietuvos mokslu akademijos Vrublevskiu biblioteka fondas 17 , sygn. 9 .

Lietuvos valstybès istorijos archyvas [LVIA] fondas SA, sygn. 13932, 13933, 13934, 13935, 13936, 13937, 13938, 13939.

Nacyjanalny histaryczny archiu Biełarusi, Minsk [NGAB] fond 1722, wopis 1 , sprawa 12, 13, 14 .

\section{ŹRÓDEA DRUKOWANE}

[Oraczewski F.], Relacya z poselstwa odprawionego na seymie extraordynaryjnym warszawskim. zaczętym roku... 1773 [...] na seymiku poselskim w roku 1776 dnia 15 julij [...] w Proszowicach, [b.m. i d.].

Akta sejmikowe województwa lubelskiego 1572-1632, oprac. H. Gmiterek, Lublin 2016.

Akta sejmikowe województw poznańskiego i kaliskiego. Lata 1696-1732, wyd. M. Zwierzykowski, Poznań 2008.

Akta sejmikowe województw poznańskiego i kaliskiego. Lata 1733-1763, wyd. M. Zwierzykowski, Poznań 2015.

Akta sejmikowe województw poznańskiego i kaliskiego. Lata 1668-1675, wyd. M. Zwierzykowski, R. Kołodziej, A. Kamieński, Poznań 2018.

Akta sejmikowe województw poznańskiego i kaliskiego. Lata 1676-1695, wyd. M. Zwierzykowski, R. Kołodziej, A. Kamieński, Poznań 2018.

Akta sejmikowe ziemi chełmskiej 1572-1668, oprac. W. Bondyra, H. Gmiterek, J. Ternes, Lublin 2013.

Akta sejmiku kowieńskiego z lat 1733-1795, wyd. M. Jusupović, Warszawa 2019. Akta sejmiku podolskiego in hostico 1672-1698, oprac. J. Stolicki, Kraków 2002. Lauda ziemi rawskiej i województwa rawskiego 1583-1793, red. M. Nagielski, oprac. M. Bak, M. Borkowski, K. Chłapowski, A. Haratym, T. Płóciennik, Ł. Przybyłek, E. Walczuk, Warszawa 2017.

Lietuvos Dzidžiosios Kunigaikštystès seimeliu instrukcijos (1788-1790), parengė R. Jurgaitis, A. Stankevič, A. Verbickienè, Vilnius 2015.

Pamiętniki Józefa Kossakowskiego biskupa inflanckiego 1738-1788, wyd. A. Darowski, Warszawa 1891. 
Volumina legum, t. VII-IX, wyd. J. Ohryzko, Petersburg 1860, t. IX, Kraków 1889.

Zbior mów, głosów, przymówien, manifestów, remanifestów, etc., mianych na seymie roku 1786, t. II, Warszawa 1787.

\section{Opracowania}

Achremczyk S., Sejmik generalny Prus Królewskich 1526-1772, Olsztyn 2016.

Adolphowa K., Szlachta litewska wobec Zbioru Praw Andrzeja Zamoyskiego ( $w$ swietle litewskich instrukcyj poselskich $z$ lat 1776, 1778, 1780, 1782), [w:] Księga pamiatkowa Koła historyków Słuchaczy USB w Wilnie, Wilno 1933, s. $156-188$.

Aniszczenko E., Szlachta Lidskogo powieta. Spisok. XVIII st., Minsk 2013.

Bednaruk W., Sejmiki lubelskie $w$ okresie stanisławowskim (1764-1794), Lublin 2011.

Buben V., Rozdwojone wybory urzędników ziemskich na sejmiku elekcyjnym województwa nowogródzkiego 5 lutego 1777 roku, „Zeszyty Naukowe Uniwersytetu Jagiellońskiego. Prace Historyczne" 2006, z. 133, s. 55-71.

Butterwick R., Polska rewolucja a Kościół katolicki 1788-1792, przekł. M. Ugniewski, Kraków 2012.

Danilczyk A., W kregu afery Dogrumowej. Sejm 1786 roku, Warszawa 2010.

Deputaci Trybunału Głównego Wielkiego Księstwa Litewskiego 1697-1794. Spisy, red. A. Rachuba, oprac. A. Rachuba, P.P. Romaniuk, współpraca A. Macuk, J. Aniszczenko, Warszawa 2004.

Filipczak W., Anna z Pociejów Tyszkiewiczowa, wojewodzina smoleńska. Rola polityczna w czasach Rady Nieustajacej, [w:] Kobiety i władza w czasach dawnych, red. B. Czwojdrak, A.A. Kluczek, Katowice 2015, s. 405-434.

Filipczak W., Ekonomie litewskie w polityce sejmikowej Stanisława Augusta po upadku Antoniego Tyzenhauza (1780-1783), „Przegląd Nauk Historycznych” 2006, R. V, nr 1 (9), s. 235-276.

Filipczak W., Elekcje ziemskich urzędników sadowych w czasach Rady Nieustajacej, [w:] Wokół wolnych elekcji w państwie polsko-litewskim XVI-XVIII wieku. O znaczeniu idei wyboru - między prawami a obowiazkami, red. M. Markiewicz, D. Rolnik, F. Wolański, Katowice 2016, s. 582-597.

Filipczak W., Instrukcje dla posłów z Wielkiego Księstwa Litewskiego na Sejm Wielki. Uwagi na temat nowego litewskiego wydawnictwa źródłowego (rec.: Lietuvos Dzidžiosios Kunigaikštystès seimeliu instrukcijos [1788-1790], parenge Robertas Jurgaitis, Adam Stankevič, Asta Verbickiene, UAB „Vitae Litera”, Vilnius 2015, ss. 436), „Przegląd Nauk Historycznych” 2017, R. XVI, nr 2, s. 302314. https: / / doi.org/10.18778/1644-857X.16.02.15

Filipczak W., Rugi poselskie i losy „rozdwojonych” sejmików przedsejmowych 1778-1786, „Czasopismo Prawno-Historyczne” 1997, t. XLIX, z. 1-2, s. 65-85.

Filipczak W., Sejm 1778 roku, Warszawa 2000.

Filipczak W., Sejmiki $w$ Wiłkomierzu $w$ czasach dominacji Antoniego Tyzenhauza (1777-1780), [w:] Parłamientaryzm u Wialikim Kniastwie Litouskim u XVIII stahoddzi, składalniki A. Macuk, R. Jurgaitis (Aktualnyje problemy istorii i kultury. Zbornik nawukowych artykułau, wypusk 2), Minsk 2020, s. 230-258. 
Filipczak W., Sejmiki powiatu wiłkomierskiego w latach 1781-1784, „Zapiski Historyczne" 2020, t. LXXXV, z. 2, s. 67-93.

Filipczak W., Sejmiki województwa płockiego 1780-1786, „Przegląd Nauk Historycznych" 2009, R. VIII, nr 2, s. 23-62.

Filipczak W., Sejmiki ziemi czerskiej 1780-1786, „Przegląd Nauk Historycznych” 2010, R. IX, nr 1, s. 139-179.

Filipczak W., Życie sejmikowe prowincji wielkopolskiej w latach 1780-1786, Łódź 2012.

Frejlich K., (rec.) Adam Stankevič, Lietuvos Vyriausiojo Tribunolo veikla XVIII amžiaus antroje pusejje, Lietuvos istorijos institutas, Vilnius 2018, ss. 528, il., ISBN 978-609-8183-42-9, „Rocznik Lituanistyczny” 2018, t. IV, s. 172-175.

Jurgaitis R., Funkcjonowanie sejmiku wileńskiego w latach 1717-1795: między szlacheckim parlamentaryzmem a samorzadem, [w:] Praktyka życia publicznego w Rzeczypospolitej Obojga Narodów w XVI-XVIII wieku, red. U. Augustyniak, A.B. Zakrzewski, Warszawa 2010, s. 35-53.

Jurgaitis R., Nuo bajoriškosios savivaldos iki parlamentarizmo: Vilniaus seimelio veikla 1717-1795 m. Monografija, Vilnius 2016.

Jurgaitis R., Vilniaus seimelio veikla 1717-1795 m. Daktaro disertacija, Kaunas 2007 [dysertacja doktorska w formacie .pdf].

Jusupović M., Instrukcje kowieńskie z lat 1733-1795 jako głos szlachty w sprawach powiatowych, „Klio” 2019, nr 3, s. 35-58.

Jusupović M., Problem legalnego miejsca sejmików jako element rywalizacji politycznej: na przykładzie sejmików kowieńskich za panowania Stanisława Augusta, „Przegląd Wschodni” 2018, t. XIV, z. 4, s. 841-854.

Jusupović M., Prowincjonalna elita litewska $w$ XVIII wieku. Działalność polityczna rodziny Zabiełłów w latach 1733-1795. Warszawa 2014.

Jusupović M., Uczestnicy sejmików kowieńskich w czasach Augusta III $i$ Stanisława Augusta Poniatowskiego - teoria i praktyka, „Rocznik Lituanistyczny” 2016, t. II, s. 127-142.

Kalenkiewiczówna A., Rozkład partii Tyzenhauza na tle sejmików litewskich, [w:] Księga pamiatkowa Koła historyków Słuchaczy USB w Wilnie, Wilno 1933, s. $121-155$.

Konieczna D., Ustrój i funkcjonowanie sejmiku brzesko-litewskiego w latach 15651763, Warszawa 2012.

Kościałkowski S., Antoni Tyzenhauz. Podskarbi nadworny litewski, t. I-II, Londyn 1970-1971.

Lityński A., Sejmiki województwa płockiego przed i w czasie Sejmu Czteroletniego. $Z$ badań nad organizacja i funkcjonowaniem, [w:] $W$ dwusetna rocznice wolnego Sejmu. Ludzie-państwo-prawo czasów Sejmu Czteroletniego, red. A. Lityński, Katowice 1988, s. 76-108.

Lityński A., Sejmiki ziemskie 1764-1793. Dzieje reformy, Katowice 1988.

Lityński A., Z problematyki klasyfikacji sejmików ziemskich, „Prace Naukowe Uniwersytetu Ślaskiego w Katowicach” 1969, nr 5, Prace Prawnicze 1, s. 89-105.

Macuk A., Baraćba mahnackich hrupowak u WKE (1717-1763 hh.), Minsk 2010. 
Macuk A., Pasolskija sojmiki Słonimskaha pawieta u panawannie Auhusta III, [w:] Da swajoj historyi: Siaredniawieczcza i Ranni Nowy czas: zbornik nawukowych artykułau, pryswieczanych pamiaci Pauła Łojki, red. W.A. Waronin, Minsk 2013, s. 104-118.

Macuk A.U., Reczyckija pawiatowyja sojmiki u bieskaraleuie 1764 h., „Izwiestija Gomielskogo gosudarstwiennogo uniwiersitieta imieni F. Skoriny” 2018, nr 4 (109), s. 48-55.

Michalski J., Sejm w czasach panowania Stanisława Augusta, [w:] Historia sejmu polskiego, t. I, red. J. Michalski, Warszawa 1984, s. 350-419.

Michalski J., Sejmiki poselskie 1788 roku, cz. 1-2, „Przegląd Historyczny” 1960, t. LI, z. 1-2, s. 52-71, 331-365.

Rachuba A., Wielkie Księstwo Litewskie w systemie parlamentarnym Rzeczypospolitej w latach 1569-1763, Warszawa 2002.

Rolnik D., Sejmiki poselskie mozyrskie $w$ latach 1778-1786 i ich reprezentanci na sejmach Rzeczypospolitej, [w:] Parłamientaryzm u Wialikim Kniastwie Litouskim u XVIII stahoddzi, składalniki A. Macuk, R. Jurgaitis (Aktualnyje problemy istorii $i$ kultury. Zbornik nawukowych artykułau, wypusk 2), Minsk 2020, s. $258-280$.

Rolnik D., Województwo mińskie i Jeleńscy w życiu publicznym Rzeczypospolitej $w$ latach 1764-1795 w swietle ich korespondencji, Katowice 2018.

Stankevič A., Lietuvos Vyriausiojo Tribunolo veikla XVIII a. II pusejje: bajoriškosios teisés raiška. Dakataro disertacija, Vilnius 2013 [dysertacja doktorska w formacie .pdf].

Szczygielski W., Referendum trzeciomajowe. Sejmiki lutowe 1792 roku, Łódź 1994.

Urzędnicy Wielkiego Księstwa Litewskiego. Spisy, t. I (Województwo wileńskie XIV-XVIII wiek), red. A. Rachuba. oprac. H. Lulewicz, A. Rachuba, P.P. Romaniuk, współpraca U. Jemialianczuk, A. Macuk, Warszawa 2004.

Urzędnicy Wielkiego Księstwa Litewskiego. Spisy, t. II (Województwo trockie XIVXVIII wiek), red. A. Rachuba, oprac. H. Lulewicz, A. Rachuba, P.P. Romaniuk, A. Haratym, współpraca A. Macuk, J. Aniszczanko, Warszawa 2009.

Włodarczyk J., Sejmiki łęczyckie, Łódź 1973.

Zakrzewski A.B., Sejmiki Wielkiego Księstwa Litewskiego XVI-XVIII w. Ustrój i funkcjonowanie: sejmik trocki, Warszawa 2000.

Zakrzewski A.B., Sejmiki Wielkiego Księstwa Litewskiego epoki stanisławowskiej (do 1788 r.). Zmiany w ustroju i funkcjonowaniu, [w:] Ziemie pótnocne Rzeczypospolitej polsko-litewskiej $w$ dobie rozbiorowej 1772-1815, red. M. Biskup, Warszawa-Torun 1996, s. 59-66.

Zakrzewski A.B., Wielkie Księstwo Litewskie (XVI-XVIII w.). Prawo - ustrój- spoŁeczeństwo, Warszawa 2013.

Zielińska Z., Poniatowski Michał Jerzy, [w:] Polski słownik biograficzny, t. XXVII, Wrocław 1983, s. 455-471.

Zwierzykowski M., Komisja Skarbowa Poznańska. Z dziejów sejmikowej administracji $i$ sadownictwa skarbowego $w$ Wielkopolsce $w$ XVII $i$ XVIII wieku, Poznań 2003.

Zwierzykowski M., Samorząd sejmikowy województw poznańskiego i kaliskiego w latach 1696-1732, Poznań 2010. 
Uwagi o sejmikach litewskich w czasach Rady Nieustajacej... 103

WitOLD FiLIPCZAK

UNIVERSITY OF LODZ

\title{
A few comments on Lithuanian sejmiks in the times of Permanent Council in the context of parliamentary practice in the county of Kaunas
}

\begin{abstract}
$\mathrm{T}_{\mathrm{in}}^{\mathrm{h}}$ his article discusses selected aspects of the way Lithuanian sejmiks proceeded in the times of Permanent Council (especially in the years 1776-1786). The author refers to particular pieces of information on the county of Kaunas which were mentioned in Akta sejmiku kowieńskiego w latach 1733-1795 published by Monika Jusupović in 2019. The information found in the abovementioned book was tested against the relevant data concerning the sejmiks of Lida and Ukmerge collected in the process of research in the archives of Minsk and Vilnius. For comparative reasons the author of this article makes use of the results of research by Lithuanian historians (on the sejmik of Vilnius) as well as the contributions of Polish and Belarusian historians. The author focuses (among others) on the functioning of economic, relational and electoral sejmiks. The article also contains information on different types of sejmik documents which were typical for Lithuanian parliamentary practice. Besides, it discusses additional items of information related to the political life in the county of Kaunas which were not referred to by M. Jusupović. The final part of the article emphasizes distinctive aspects of research on the Lithuanian parliamentary practice. Owing to the custom of signing the sejmik lauda by the unlimited number of participants, it is now possible to state roughly how large the gathering was. In the second part of the $18^{\text {th }} \mathrm{c}$. there were still considerable differences between the sejmiks in the Crown and Lithuania even though the models in respective countries tended to converge.
\end{abstract}

Keywords: sejmiks (dietines), Parliamentarism, Grand Duchy of Lithuania in $18^{\text {th }}$ c. Kaunas, Lida, Ukmergé (Vilkmergè). 